\title{
Effects of the insecticide fipronil in freshwater model organisms and microbial and periphyton communities
}

\author{
María Rosa Pino-Otín ${ }^{\mathrm{a}, *}$, Diego Ballestero ${ }^{\mathrm{a}}$, Enrique Navarro ${ }^{\mathrm{b}}$, Ana M. Mainar ${ }^{\mathrm{c}}$, Jonatan Val ${ }^{\mathrm{a}, \mathrm{b}}$ \\ ${ }^{a}$ Universidad San Jorge, Villanueva de Gállego, 50830 Zaragoza, Spain \\ b Pyrenean Institute of Ecology, CSIC, Av. Montañana 1005, Zaragoza 50059, Spain \\ c I3A, Universidad de Zaragoza, c/ Mariano Esquillor s/n, 50018 Zaragoza, Spain
}

\section{H I G H L I G H T S}

- Fipronil produces the greatest effect on D. magna which increases with temperature.

- Fipronil affects the photosynthetic yield of $C$. reinhardtii at $20^{\circ} \mathrm{C}$.

- The freshwater periphyton are sensitive to fipronil in a time-dependent manner.

- River water medium decreases fipronil toxicity to C. reinhardtii and periphyton.

- Metabolism of aquatic and soil bacteria communities is little affected by fipronil.

\section{A R T I C L E I N F O}

\section{Article history:}

Received 3 June 2020

Received in revised form 25 September 2020

Accepted 29 September 2020

Available online $\mathrm{xxxx}$

Editor: Daniel Wunderlin

\section{Keywords:}

Fipronil

Ecotoxicity

Daphnia magna

Chlamydomonas reinhardtii

River periphyton

Microbial communities

\section{G R A P H I C A L A B S T R A C T}

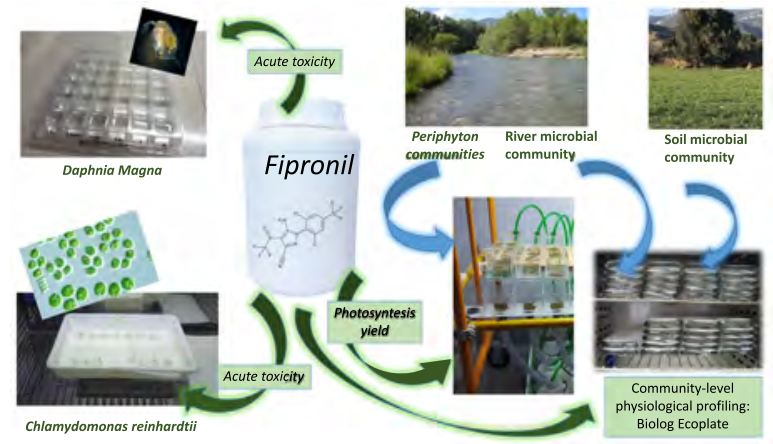

\begin{abstract}
A B S T R A C T
Fipronil is a broad-spectrum insecticide whose release in the environment damages many non-target organisms. This study evaluated the toxicity of fipronil at two biological levels using in vivo conditions and environmentally relevant concentrations: the first based on two model organisms (aquatic invertebrate Daphnia magna and the unicellular freshwater alga Chlamydomonas reinhardtii) and a second based on three natural communities (river periphyton and freshwater and soil microbial communities). The physicochemical properties of fipronil make it apparently unstable in the environment, so its behaviour was followed with high performance liquid chromatography (HPLC) under the different test conditions. The most sensitive organism to fipronil was D. magna, with median lethal dose $\left(\mathrm{LC}_{50}\right)$ values from 0.07 to $0.38 \mathrm{mg} / \mathrm{L}$ (immobilisation test). Toxicity was not affected by the media used (MOPS or river water), but it increased with temperature. Fipronil produced effects on the photosynthetic activity of $C$. reinhardtii at $20^{\circ} \mathrm{C}$ in $\mathrm{MOPS}\left(\mathrm{EC}_{50}=2.44 \mathrm{mg} / \mathrm{L}\right.$ ). The freshwater periphyton presented higher sensitivity to fipronil (photosynthetic yield $\mathrm{EC}_{50}$ of $0.74 \mathrm{mg} / \mathrm{L}$ ) in MOPS and there was a timedependent effect (toxicity increased with time). Toxicity was less evident when periphyton and C. reinhardtii tests were performed in river water, where the solubility of fipronil is poor. Finally, the assessment of the metabolic profiles using Biolog EcoPlates showed that bacteria communities were minimally affected by fipronil. The genetic identification of these communities based on 16S rRNA gene sequencing revealed that many of the taxa are specialists in degrading high molecular weight compounds, including pesticides. This work allows us to better understand the impact of fipronil on the environment at different levels of the food chain and in different environmental conditions, a necessary point given its presence in the environment and the complex behaviour of this compound.
\end{abstract}

(c) 2020 Elsevier B.V. All rights reserved.

\footnotetext{
* Corresponding author at: Universidad San Jorge, Campus Universitario Villanueva de Gállego Autovía A-23 Zaragoza-Huesca, km. 510, 50830 Villanueva de Gállego, Zaragoza, Spain. E-mail addresses: rpino@usj.es, $\quad$ URL: https://www.usj.es (M.R. Pino-Otín), dballestero@usj.es (D. Ballestero), enrique.navarro@ipe.csic.es (E. Navarro), ammainar@unizar.es (A.M. Mainar), jval@colegiointernacionalanfora.com (J. Val).
} 


\section{Introduction}

Fipronil is a widely used, broad-spectrum phenylpyrazole insecticide that can control many insects, including cockroaches, mosquitoes, locusts, termites, thrips, rootworms, ticks and fleas, at both larval and adult stages (Gunasekara et al., 2007). Moreover, it is used as a plant protection product as well as a veterinary drug (reviewed by Wang et al., 2016a, 2016b). Fipronil has gained popularity throughout the world for pest management, including agricultural and urban environments due to its effectiveness against insects that are resistant to other agents, such as pyrethroids, organophosphates and carbamates (Bobe et al., 1997).

Fipronil inhibits Gamma-Aminobutyric acid (GABA) receptor chloride channels, disrupting normal neuronal influx and resulting in the accumulation of GABA at synaptic junctions which causes hyperexcitation of the nervous system, severe paralysis and, finally, death (Wang et al., 2016a, 2016b; Gunasekara et al., 2007).

Fipronil is a chiral molecule; each enantiomer presents different toxicity (Qu et al., 2014). It is unstable in the environment because it is affected by UV radiation (Mianjy and Niknafs, 2013), pH (Ramesh and Balasubramanian, 1999) and temperature (Ma et al., 2012). It is biodegradable (Peret et al., 2010; Hussain et al., 2016), and some of its transformation products show enhanced toxicity against non-target organisms compared to the parent compound (Michel et al., 2016). Reports have indicated that temperature influences the toxicity of insecticides on target organisms (Ma et al., 2012), although the effects are irregular.

Due to its wide use, fipronil is currently present in soils and surface and ground waters. This distribution poses risks to the environment and provokes undesirable effects on non-target organisms as bees (Kiljanek et al., 2016; Lourenco et al., 2012; Sanchez-Bayo et al., 2016), reptiles (Maute et al., 2015; Peveling and Demba, 2003), birds (Kitulagodage et al., 2011), mammals (Szegedi et al., 2005; Roques et al., 2012; de Oliveira et al., 2012; Khan et al., 2015) and soil microflora (Ahemad and Khan, 2011a).

The presence of fipronil in different aquatic environments has been reported around the world (Tousova et al., 2017; Wu et al., 2015; Maruya et al., 2016; Toan et al., 2013; Delgado-Moreno et al., 2011). The fipronil concentration in freshwaters ranges from 0.5 (Michel et al., 2016) up to $2000 \mathrm{ng} / \mathrm{L}$ (Ensminger et al., 2013). Gan et al. (2012) found a median concentration of $204-440 \mathrm{ng} / \mathrm{L}$ for fipronil and its derivatives in urban residential runoff. In addition, wastewater treatment plants have shown fipronil concentrations as large as $1388 \mathrm{ng} / \mathrm{L}$ (Sadaria et al., 2017) and 12-31 ng/L (Supowit et al., 2016). Fipronil has also been occasionally detected in drinking water (in 95\% of collected samples), with median concentrations of $40 \mathrm{ng} / \mathrm{L}$ (Toan et al., 2013) and in groundwater irrigated fields at a maximum concentrations of $3440 \mathrm{ng} / \mathrm{L}$ (da Silva et al., 2011).

Based on these data, fipronil can reach aquatic environments (Garrison, 2011), and direct or indirect effects on aquatic organisms can be expected. Fipronil toxicity has been assessed in different freshwater organisms (Gripp et al., 2017; Schlenk et al., 2001; Bedient et al., 2005; Beggel et al., 2012), including small aquatic invertebrates, such as oligochaetes (Liu et al., 2012) and cladocerans (Hayasaka et al., 2012b; Iwafune et al., 2011). Less information can be found in the literature regarding the effect of fipronil on phytoplankton (Overmyer et al., 2007; Qu et al., 2014). All these studies using individual species have limited environmental relevance because they only partially show the impact on biological communities (Hayasaka et al., 2012a; Møhlenberg et al., 2001). Communities form groups or associations of different populations or species that occupy the same geographic area at the same time and that usually have the ability to resist (resistance) and return (resilience) to change, so they are realistic indicators of environmental impacts. Much less information can be found in the literature regarding the effect of fipronil on aquatic communities, despite the importance of such information for obtaining a realistic environmental impact assessment. As far as we know, the only study available demonstrated the cumulative impacts of fipronil on aquatic communities - paddy mesocosms - with a significant decrease in the abundance of benthic organisms during both years in insecticide-treated fields (Hayasaka et al., 2012a).

Therefore, it is necessary to determine if the doses at which fipronil presents toxicity not only in individual organisms but also in natural communities are in the range of those that have been described for this insecticide in aquatic and edaphic environments.

Our hypothesis was that fipronil would not only present toxic effects in model organisms but would also be capable of affecting natural water and soil communities which would more realistically demonstrate the risk of this insecticide for the environment.

Therefore, in this study we evaluate the ecotoxicity of fipronil at two biological levels: first, two model organisms (aquatic invertebrate Daphnia magna and the unicellular freshwater alga Chlamydomonas reinhardtii) and second, three natural communities (river periphyton and freshwater and soil microbial communities). We utilise the following endpoints: acute toxicity tests ( $D$. magna), photosynthetic yield reduction (C. reinhardtii and periphyton communities), and the ability of aquatic and soil microbial communities to degrade different carbon sources. To increase the environmental relevance of the assessment, the effect of temperature and different assay media is included as a modulating factor for fipronil toxicity.

\section{Material and methods}

\subsection{Fipronil}

Fipronil $\left(\mathrm{C}_{12} \mathrm{H}_{4} \mathrm{Cl}_{2} \mathrm{~F}_{6} \mathrm{~N}_{4} \mathrm{OS}\right.$, CAS 120068-37-3) was purchased from Cymit Chemical S.L., with a minimum purity of $97.0 \%$ and a molecular weight of 437.14 .

\subsection{D. magna assay}

D. magna (water flea) assays were performed in accordance with OECD, (2004) guidelines and following the standard operational procedures of the Daphtoxkit FTM magna (1996), purchased from Vidrafoc Daphtoxkit (number DM121219) and stored at $4{ }^{\circ} \mathrm{C}$.

A TOXKIT incubator (ECOTEST, model CH-0120D-AC/DC) was used for $D$. magna egg incubation for $72 \mathrm{~h}$ at $20-22{ }^{\circ} \mathrm{C}$ with $6000 \mathrm{~lx}$ light. The neonates ( $22 \mathrm{~h}$ old) were pre-fed with one vial of spirulina microalgae. After $2 \mathrm{~h}$ of feeding, D. magna were exposed to the following fipronil concentrations: $10,50,100,250$ or $500 \mu \mathrm{g} / \mathrm{L}$, to cover ranges described in previous studies (Hayasaka et al., 2012b; Iwafune et al., 2011; USEPA, 2000). There were five replicates with five organisms per concentration. This procedure was replicated for six plates, three of which contained synthetic freshwater provided by the Daphtoxkit for the negative control and for dilutions. The other three plates used water collected from the Gallego River, a tributary of the Ebro River (northeast Spain) in Villanueva de Gállego (Zaragoza, Spain) on 16 July 2016. The water samples were transported to the laboratory in $<15 \mathrm{~min}$ and stored at $4{ }^{\circ} \mathrm{C}$ until use. The physicochemical characteristics of this river water are provided in Table 1 . The $\mathrm{pH}$ was adjusted to a range between 7 and 8 in all cases, using $\mathrm{NaOH}$. Plates were incubated from 18 to $22{ }^{\circ} \mathrm{C}$, according to OECD (2004) guidelines. However, to study the effects of temperature on fipronil toxicity, plates with both synthetic and River Gallego water were incubated in complete darkness for $24 \mathrm{~h}$ at 18,23 or $25^{\circ} \mathrm{C}$. After a 24 -h exposure, immobilised individuals (unable to swim for $15 \mathrm{~s}$ after gentle agitation of the test vial) were checked and counted. The results were calculated as the $\mathrm{EC}_{50}$ (chemical concentration resulting in 50\% immobilisation). 
Table 1

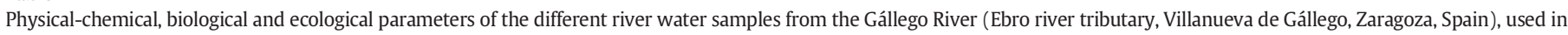
the assays.

\begin{tabular}{|c|c|c|c|c|c|c|}
\hline \multirow[t]{2}{*}{ Assay } & \multirow[t]{2}{*}{ D. magna } & \multirow[t]{2}{*}{ C. reinhardtii } & \multirow{2}{*}{$\begin{array}{l}\text { Bacterial communities } \\
\text { of river }\end{array}$} & \multicolumn{3}{|c|}{ Periphyton communities } \\
\hline & & & & $\begin{array}{l}\text { Biofilm substrate } \\
\text { placement }\end{array}$ & $\begin{array}{l}15 \text { days of the Biofilm } \\
\text { substrate placement }\end{array}$ & $\begin{array}{l}\text { Biofilm substrate } \\
\text { collection }\end{array}$ \\
\hline Date & $13-7-2016$ & 29-09-17 & $17-10-17$ & $16-05-17$ & $20-06-17$ & $11-07-17$ \\
\hline Conductivity ( $\mu \mathrm{s} / \mathrm{cm})$ & 2423.8 & 2348 & 2853 & 2368 & 2187 & 2363 \\
\hline $\mathrm{pH}$ & 7.8 & 7.7 & 7.92 & 8.17 & 8.14 & 8.46 \\
\hline Total suspended solids (mg/L) & 22 & 2.2 & 4.2 & 4.3 & 3.5 & 12.1 \\
\hline Total dissolved solids (mg/L) & 563 & 1716 & 1360 & 1640 & 1500 & 1560 \\
\hline Fluorides (mg/L) & & 0.088 & 0.094 & 0.065 & 0.05 & 0.051 \\
\hline Chlorides (mg/L) & 58.1 & 414.625 & 507.599 & 187.897 & 190.952 & 190.209 \\
\hline Nitrites $(\mathrm{mg} / \mathrm{L})$ & 0.49 & 0 & 0 & 0 & 0 & 0 \\
\hline Bromides (mg/L) & & 0.392 & 0.567 & 0.253 & 0.214 & 0.264 \\
\hline Nitrates $(\mathrm{mg} / \mathrm{L})$ & & 14.827 & 13.563 & 6.668 & 5.936 & 5.285 \\
\hline Phosphates (mg/L) & 0.28 & 0 & 0 & 0 & 0 & 0 \\
\hline Sulphates $(\mathrm{mg} / \mathrm{L})$ & 157.3 & 330.936 & 383.113 & 162.035 & 163.198 & 168.133 \\
\hline Total alkalinity (mg/L) & & 262.1 & 223.26 & 276.24 & 215.18 & 236.68 \\
\hline Sodium (mg/L) & & 255.309 & 332.718 & 196.548 & 191.93 & 164.028 \\
\hline Ammonium (mg/L) & $>0,10$ & 1.797 & 0 & 0.033 & 0.038 & 0 \\
\hline Potassium (mg/L) & & 3.103 & 3.623 & 2.098 & 2.135 & 2.49 \\
\hline Calcium $(\mathrm{mg} / \mathrm{L})$ & & 178.587 & 198.203 & 130.42 & 128.442 & 115.446 \\
\hline Magnesium (mg/L) & & 29.776 & 31.683 & 33.391 & 19.758 & 7.473 \\
\hline Total organic carbon $(\mathrm{mg} / \mathrm{L})$ & 5.5 & 1.3 & 2.2 & 1.42 & 1.6 & 1.11 \\
\hline Total nitrogen $(\mathrm{mg} / \mathrm{L})$ & & & & 4.54 & 3.93 & 3.72 \\
\hline Chlorophyll a ( $\mu \mathrm{g} / \mathrm{L})$ & & & & 2.01 & 2.47 & 18.54 \\
\hline Chlorophyll b ( $\mu \mathrm{g} / \mathrm{L})$ & & & & 0.76 & 1.22 & 6.53 \\
\hline Chlorophyll c $(\mu \mathrm{g} / \mathrm{L})$ & & & & 96.80 & 78.78 & 201.20 \\
\hline TSI (Chlorophyll a) & & & & 37.00 & 39.00 & 59.00 \\
\hline Margalef index & & & & 1.36 & 1.84 & 2.00 \\
\hline Moss index & & & & 1.27 & 1.62 & 1.77 \\
\hline
\end{tabular}

\subsection{C. reinhardtii assay}

Unicellular green algae C. reinhardtii (CC125) were cultivated in standard growth medium (Szivak et al., 2009); the $\mathrm{pH}$ was adjusted to 7.5. Algae were maintained in the exponential growth phase and under controlled conditions ( $90 \mathrm{rpm}, 130 \mu \mathrm{E}$ photosynthetically active radiation (PAR) $\mathrm{m}^{-2} \mathrm{~s}^{-1}$ between 23 and $26^{\circ} \mathrm{C}$ ). The exposure medium comprised river water collected on 29 September 2017 from the Gallego River (Table 1) or standard buffer solution, namely $0.01 \mathrm{nM} \mathrm{3-(N-}$ morpholino)-propanesulfonic acid (MOPS) (CAS 1132-61-2; purity $\geq 99 \%$; Merck). The water samples were transported to the laboratory in $<15 \mathrm{~min}$ and stored at $4{ }^{\circ} \mathrm{C}$ until use. Before testing, the water samples were kept under agitation with strong magnetic stirring to ensure oxygenation. In addition, the following measures were made in situ at the river: conductivity $(2680 \mu \mathrm{S} / \mathrm{cm})$, dissolved oxygen $\left(4.4 \mathrm{mg} / \mathrm{L} \mathrm{O}_{2}\right.$ and \% sat, $\left.52.4 \mathrm{mg} / \mathrm{L} \mathrm{O}_{2}\right), \mathrm{pH}(7.6)$ and water temperature $\left(22.3^{\circ} \mathrm{C}\right)$.

Later, algae were centrifuged (10 min, $3000 \mathrm{rpm}$ ) and adjusted to an optical density (OD) of 0.15 for the test suspensions. The OD was measured by a spectrophotometer ( $\lambda 685 \mathrm{~nm})$. After pre-tests to adjust the concentration range, the fipronil concentrations $(0.25,0.5,0.75,1$, 1.5 or $2 \mathrm{mg} / \mathrm{L}$ ) were tested under similar light and shaking conditions as those during growth. The $\mathrm{pH}$ of the solutions was checked at the beginning and end of the measurements. Experiments were performed at 20,25 or $30^{\circ} \mathrm{C}$. The algal photosynthetic yield of photosystem II was measured using a mini-PAM fluorometer (Walz, Effeltrich, Germany), as previously described (Pino et al., 2016). Each concentration was tested in triplicate. $\mathrm{EC}_{50}$ values (photosynthetic yield) after 6-h exposures were calculated.

\subsection{Periphyton communities assay}

\subsubsection{Colonisation}

Periphyton communities were obtained from the Gallego River (Zaragoza, Spain). Artificial substrates, consisting of a flat, heavy rock equipped with methacrylate racks containing 24 microscope slides, were placed under water (10-15 cm depth) in May 2017. Periphyton reached an average thickness of $0.75 \mathrm{~mm}$. This methodological approach has been developed and tested in a previous study (Navarro et al., 2002).

\subsubsection{Periphyton characterisation and water analysis}

After the colonisation period, periphyton-colonised slides were transported to the laboratory, and one slide was prepared for taxonomic identification. Diatom frustules were obtained by oxidation with hydrogen peroxide and were mounted on permanent slides with Naphrax resin. Cell count and identification were performed using a Leica light microscope at $1000 \times$ total magnification (diatoms) or 100,400 and $1000 \times$ total magnification (other microalgae). Results are expressed as the number of individuals per $\mathrm{cm}^{2}$ of biofilm as well as density (number of individuals per $\mathrm{mL}$ ). The river water was measured at the start of colonisation, 15 days later and at the end of colonisation. Substrates were collected with a sample of river water (Table 1). Water samples were also analysed for chlorophyll $a, b$ and $c$. The Trophic State and Margalef Indexes were calculated.

\subsubsection{Dose and time response curves in flow-through artificial channels}

Flow through methacrylate channels (90 cm long and $10 \mathrm{~cm}$ wide) connected to separate water reservoirs was used for dose-response experiments with periphyton (Fig. 1). Reservoirs were submerged in a thermostatic bath at $23{ }^{\circ} \mathrm{C}$. Aquarium pumps re-circulated the water from the reservoirs through every channel at $0.113 \mathrm{~m}^{3} / \mathrm{h}$. Every reservoir contained $4 \mathrm{~L}$ of water. Light was provided by fluorescence lamps (Blau Aquaristic T5HO: $39 \mathrm{~W}, 10,000 \mathrm{~K}$ and $80 \mu \mathrm{mol}$ photon $\mathrm{m}^{-2} \mathrm{~s}^{-1}$ at the channel surface). Slides colonised by periphyton were placed horizontally on the bottom of the flow-through channels (Fig. 1). The effect of fipronil on the photosynthetic efficiency of the periphyton was evaluated as described by Val et al. (2016), using a portable pulse amplitude modulation fluorometer (MINI-PAM, Walz). The yield reflects the efficiency of the photochemical energy conversion process (Consalvey et al., 2005). 


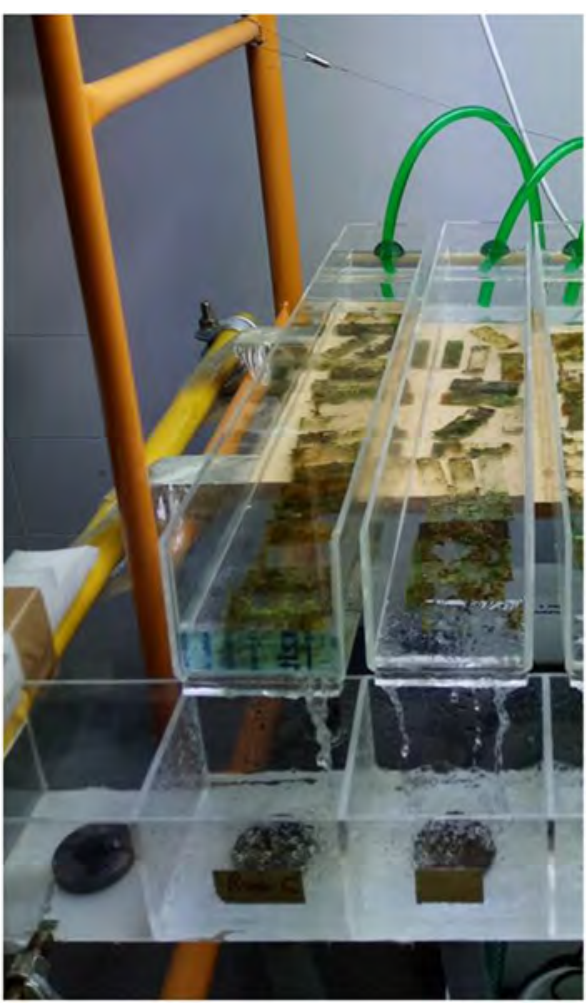

Fig. 1. Flow-through artificial channels (mesocosm) where effects of fipronil on river Periphyton communities were analysed. Periphyton-colonised slides collected from the Gállego River (Villanueva de Gállego, Zaragoza, Spain) can be seen inside the channels.

The dose-response experiment was designed using $0.1,0.25,0.75,1$ and $2 \mathrm{mg} / \mathrm{L}$ of fipronil according to pre-tests. Toxicity was evaluated at these concentrations in two different media to assess the possible effect of chemical composition of river water: the river water or buffer solution (MOPS), adjusted to a $\mathrm{pH}$ of 7.5 using $\mathrm{KOH}$. One channel with river water and another with MOPS, both without fipronil, were used as the negative controls. The photosynthetic efficiency of the periphyton was measured in triplicate after 1 and $13 \mathrm{~h}$. Three slides of periphyton were placed in each channel.

In addition to the dose-response experiment, a time-response curve with regard to the effect of fipronil on periphyton was performed. For this endeavour, one periphyton slide was placed in the flow-through artificial channels with river water and the other with MOPS; both were exposed to $2 \mathrm{mg} / \mathrm{L}$ fipronil (the maximum soluble concentration in water). The photosynthetic efficiency was measured every $30 \mathrm{~min}$ for $24 \mathrm{~h}$.

\subsection{Water and soil microorganisms assays}

\subsubsection{Water samples}

Water samples were collected on 17 October 2017 from the Gallego River and transported to the laboratory according to standard procedures. The physicochemical characteristics of this water are provided in Table 1 . In addition, conductivity $(2340 \mu \mathrm{S} / \mathrm{cm})$, dissolved oxygen ( $11.1 \mathrm{mg} / \mathrm{L} \mathrm{O}_{2}$ and \% sat, $128.2 \mathrm{mg} / \mathrm{L} \mathrm{O}_{2}$ ), $\mathrm{pH}(8.1)$ and temperature $\left(22.1^{\circ} \mathrm{C}\right)$ were measured in situ. For genetic analysis, microorganisms were extracted from $1 \mathrm{~L}$ of the river water that was filtered through a $0.22 \mu \mathrm{m}$ filter, resuspended in a Falcon tube with $10 \mathrm{~mL}$ Milli- $Q$ water, centrifuged at $5000 \mathrm{~g}$ and stored at $-80^{\circ} \mathrm{C}$ until sequencing.

\subsubsection{Soil samples}

The soil was obtained on 30 October 2017 from a crop field free of pesticides or other contaminants (Montañana, Zaragoza, Northeast
Spain). Soil was sieved at $<2 \mathrm{~mm}$ and stored at $4{ }^{\circ} \mathrm{C}$ until use. The texture of the soil was: $37.3 \%$ sand, $24.7 \%$ silt and $38.0 \%$ clay; the content of organic matter was $3.8 \%$; and the $\mathrm{pH}$ was between 7.8 and 8 . Microbes were extracted from $20 \mathrm{~g}$ of the soil, to which $100 \mathrm{~mL}$ of sterile water was added. In Falcon tubes with $10 \mathrm{~mL}$ Milli-Q water, they were sonicated for $1 \mathrm{~min}$ and centrifuged at $1000 \mathrm{~g}$ for $10 \mathrm{~min}$. The supernatants were collected aseptically. The process was repeated five times. The portion of the resulting supernatant containing the soil microorganisms was stored at $-4{ }^{\circ} \mathrm{C}$ to be assayed in the Biolog EcoPlate. The remaining liquid was filtered with a $0.2 \mu \mathrm{m}$ filter with a vacuum kitasato; the filter content was carefully washed with Milli-Q water and centrifuged at $5000 \mathrm{~g}$ for $10 \mathrm{~min}$. The supernatant was removed with an eyedropper and the pellets were stored at $-80{ }^{\circ} \mathrm{C}$ until sequencing.

\subsubsection{Genetic sequencing of river and soil microorganisms}

To better interpret the effect of fipronil on the metabolism of microbial communities, it is necessary to know its taxonomic composition and the predominant taxa. For this, the most accurate tool is genetic sequencing.

Genetic sequencing of microorganisms in Gállego River water samples and soil was performed in the Genomics Unit Cantoblanco, Science Park (Madrid, Spain). Bacterial genomic DNA from the samples (previously homogenised in phosphate-buffered saline [PBS]) was extracted from $200 \mu \mathrm{L}$ aliquots after proteinase $\mathrm{K}$ and RNAse digestion using Gspin columns (INTRON Biotechnology, South Korea). Quant-IT PicoGreen reagent (Thermo Fischer, EEUU) was used to determine DNA concentrations. DNA samples were used to amplify the V3-V4 region of the $16 \mathrm{~S}$ ribosomal RNA (rRNA) gene, as previously described (Caporaso et al., 2011; Caporaso et al., 2012; Pino-Otin et al., 2019b, 2019c).

Polymerase chain reaction (PCR) products included extension tails that allowed sample barcoding. Amplicon libraries were analysed using a Bioanalyzer 2100 (Agilent, EEUU), and the concentration was estimated by real-time PCR (Kapa Biosystems, Hoffmann-La Roche Switzerland). Later, DNA samples were sequenced on an Illumina MiSeq Instrument under a $2 \times 300$ protocol. Finally, reads were quality filtered according to Illumina standard values, demultiplexed and fastq files were mapped against the GreenGenes database using current applications of Base Space (16S Metagenomics, Illumina). In the run, $94.4 \%$ of the 137,961 total reads for water microorganisms passed quality filtering and $93.5 \%$ of the 154,842 total reads for soil microorganisms passed quality filtering.

\subsubsection{Microbial metabolism: ability to degrade different carbon sources}

The ability of water microbial community to utilise several carbon sources after fipronil exposure was analysed with a Biolog EcoPlate test that contains 31 different carbon sources plus a blank (water) in triplicate. Fipronil dilutions in river water containing water microorganisms $(0.1$ or $1 \mathrm{mg} / \mathrm{L})$ were prepared in a final volume of $150 \mu \mathrm{L}$ in Biolog plate wells. Regarding soil microorganisms, soil particles were removed from the supernatant containing the soil microorganisms (Section 2.5.2) by low-speed centrifugation at $500 \mathrm{~g}$ for $2 \mathrm{~min}$ before inoculating the Biolog plates. Then, the supernatant was added to each well and the same fipronil dilutions ( 0.1 or $1 \mathrm{mg} / \mathrm{L}$ ) were prepared in a final volume of $150 \mu \mathrm{L}$. Each concentration was tested in triplicate. All manipulations were performed under sterile conditions in a flow chamber. The plates were incubated in the dark at 20,25 and $30^{\circ} \mathrm{C}$ for 7 days under sterile conditions. The final $\mathrm{pH}$ for dilutions was between 7.7 and 8.1 and river water was strongly agitated with magnetic stirring before testing to ensure oxygenation.

The Optical Density (OD, $\lambda 590 \mathrm{~nm}$ ) of each well was measured just after inoculation and once a day using an Anthos 2010 microplate reader and ADAP 2.0 software (Biochrom, Ltd., Cambridge, England), as previously described (Muniz et al., 2014; Pino-Otin et al., 2019a, 
2019b, 2019c). The rate of utilisation of the carbon sources was thus assessed as the reduction of tetrazolium violet redox (Pohland, 2009).

\subsection{High performance liquid chromatography (HPLC) analysis}

The conditions studied in the ecotoxicity tests (type of medium, temperature and time) were analysed through HPLC, to monitor the behaviour and solubility of fipronil. One-hundred $\mathrm{mL}$ solutions were prepared for each studied condition. The same river water samples used in the ecotoxicity tests for $D$. magna, $C$. reinhardtii, water microorganisms and periphyton communities (see Table 1) were prepared, as well as MOPS and synthetic freshwater solutions (same than Daphnia test). Along with fipronil, ethiprole was added as an internal standard $(0.2 \mathrm{mg} / \mathrm{L}$ of each). An ultrasonic bath was used for the dissolution of the products. Solutions were prepared in triplicate at the different temperatures tested in the ecotoxicity tests and kept in darkness.

All samples were analysed using an Agilent 1100 HPLC unit coupled to the Bruker MicroTOF-Q high resolution mass spectrometer equipped with a Poroshell 120 column, with Q-TOF hybrid analyser and electrospray (APCI and APPI) systems. As a mobile phase, a ratio of 60/ 40 (acetonitrile/water) was used. Ethiprole and acetonitrile (HPLC quality) were purchased from Scharlab. Samples were analysed with an isocratic mobile phase with a flow of $1 \mathrm{~mL} / \mathrm{min}$. Five $\mu \mathrm{L}$ of each solution was injected into the equipment.

\subsection{Statistics and graphical representation}

Dose-response curves for $D$. magna mobility and $C$. reinhardtii and periphyton community photosynthetic yield were calculated with a logit logistic regression using XLSTAT (2014.5.03) software to obtain the corresponding $\mathrm{EC}_{50}$ values and standard errors (SE). Doseresponse models were statistically tested using a chi-square test. Later, $t$-tests were performed to compare parameters (i.e. $\mathrm{EC}_{50}$ ) of doseresponse curves using $\mathrm{R}$ statistical software, namely the CompParm function from the drc package.

The microbial activity of each Biolog EcoPlate microplate was expressed as the average well colour development (AWCD) and determined according Garland and Mills (1991) and a previous study (PinoOtin et al., 2019a, 2019b, 2019c) as follows:

$A W C D=\sum_{i=0}^{i=12}\left(O D_{t=x_{i}}-O D_{t=x_{0}}\right)$

where $\mathrm{OD}_{\mathrm{i}}$ is the optical density value from each well at any given time, after subtracting $\mathrm{OD}_{\mathrm{t}=\mathrm{xo}}$ from $\mathrm{OD}_{\mathrm{t}=\mathrm{xi}}$ of that well. The variance relationship between AWCD values of the three replicates and Student's independent sample $t$-tests were used to assess significance using XLSTAT software (2014.5.03).

For HPLC experiments, peak area data were obtained by integrating the fipronil and ethiprole peaks with the Data Analysis 4.2 (Bruker) programme in order to take advantage of the direct relationship that exists between the integration of the peak area and the concentration of the solution.

\section{Results}

\subsection{Effects of fipronil on D. magna}

D. magna mortality increased with temperature in both types of media (Fig. 2). Toxicity was slightly higher in river water compared to standard water at $18{ }^{\circ} \mathrm{C}$, but it was similar at the other two temperatures. The $t$-tests showed the greatest differences between river water at $18{ }^{\circ} \mathrm{C}$ versus standard water at $25^{\circ} \mathrm{C}(p=0,054)$ and river water at $25^{\circ} \mathrm{C}$ versus standard water at $18^{\circ} \mathrm{C}(p=0.068)$. In the case of synthetic water, fipronil median lethal concentration $\left(\mathrm{LC}_{50}\right)$ values (in $\mathrm{mg} / \mathrm{L}$ ) were 0.38 at $18{ }^{\circ} \mathrm{C},>0.10$ at $23{ }^{\circ} \mathrm{C},>0.07$ at $25^{\circ} \mathrm{C}$. For river water, the
$\mathrm{LC}_{50}$ values were 0.16 at $18{ }^{\circ} \mathrm{C},>0.1$ at $23^{\circ} \mathrm{C},>0.07$ at $25^{\circ} \mathrm{C}$; see Fig. 2 for confidence limits.

Notably, fipronil underwent oscillations in its solubility over $24 \mathrm{~h}$ depending on the temperature and the type of solvent (Fig. 2). In the case of Daphnia standard water, fipronil solubility increased after $24 \mathrm{~h}$, especially at 23 and $25^{\circ} \mathrm{C}$. In the case of river water, the opposite occurred: the solubility of fipronil decreased at $24 \mathrm{~h}$, especially at 23 and $25{ }^{\circ} \mathrm{C}$. Fipronil solubility was also checked in distilled water; it presented very similar results to those obtained with the standard Daphnia water (data not shown).

\subsection{Effects of fipronil on $C$. reinhardtii}

C. reinhardtii photosynthetic activity was affected by fipronil, but only at $20{ }^{\circ} \mathrm{C}$ and only in MOPS buffer (Fig. 3). LC50 and $\mathrm{LC}_{10}$ values for MOPS at this temperature were $2.44 \mathrm{mg} / \mathrm{L}$ (95\% confidence interval [CI] 1.97-3.32) and $0.12 \mathrm{mg} / \mathrm{L}(95 \% \mathrm{Cl} 0,07-0,18)$, respectively, according chi-square test.

No effects could be detected in the other experimental conditions: MOPS at $25^{\circ} \mathrm{C}$ and $30^{\circ} \mathrm{C}$ or any conditions in river water.

Fipronil solubility at $20^{\circ} \mathrm{C}$ in river water and MOPS at the beginning of the experiment and after $6 \mathrm{~h}$ was analysed through HPLC (Fig. 3, down). Under these conditions, fipronil solubility in MOPS buffer showed a slight decrease after $6 \mathrm{~h}$.

\subsection{Effects of fipronil on periphyton communities}

\subsubsection{Periphyton community analysis}

Algae from three phyla (Dinophyta, Crypotophyta and Chlorophyta) and the subclass Bacillariophyceae, together with the photosynthetic bacterial phylum Cyanobacteria, were identified (Fig. 4). Bacillariophyceae presented the greatest species diversity (17). The most common species (in decreasing order) were Achnanthes lanceolata, Amphora veneta, Cymbella silesiaca Bleisch, 1864 and Achnanthidium minutissimum. Among the green algae chlorophytes, there were up to seven different species, the most abundant being Scenedesmus sp. There were small differences in the composition and dominance of species among the 10 studied samples (one from each experimental condition), although most species were present in all samples (Supporting Information 1).

\subsubsection{Fipronil dose-response curves}

The evolution of the photosynthetic yield of the river periphyton when exposed to different doses of fipronil after 1 or $13 \mathrm{~h}$ in river water and MOPS is presented in Fig. 5. In MOPS, there was a clear decrease in photosynthetic yield as the fipronil dose increased, especially after 13 h (Fig. 5a); however, the effect was lower in river water (Fig. 5b).

The $\mathrm{LC}_{50}$ and $\mathrm{LC}_{10}$ values for MOPS were $0.74 \mathrm{mg} / \mathrm{L}(95 \% \mathrm{CI}$ $0.62-0.89$ ) and $0.02 \mathrm{mg} / \mathrm{L}$ (95\% CI 0.01-0.04), respectively (Fig. 6).

\subsubsection{Assessing the influence of time in fipronil toxicity}

Time clearly increased fipronil toxicity in MOPS $\left(\mathrm{EC}_{50 \mathrm{~T}}=10 \mathrm{~h}\right)$, but again, there was no toxicity in river water. Fig. 7 shows periphyton photosynthetic yield changes over time after exposure to $2 \mathrm{mg} / \mathrm{L}$ of fipronil in MOPS (blue line) and river water (red line) over $24 \mathrm{~h}$.

\subsubsection{Fipronil solubility in river water and MOPS}

Fipronil presented higher solubility in MOPS compared to river water at $23^{\circ} \mathrm{C}$, but it decreased progressively up to $24 \mathrm{~h}$. The solubility in river water tends to increase (Fig. $5 \mathrm{c}$ ). 

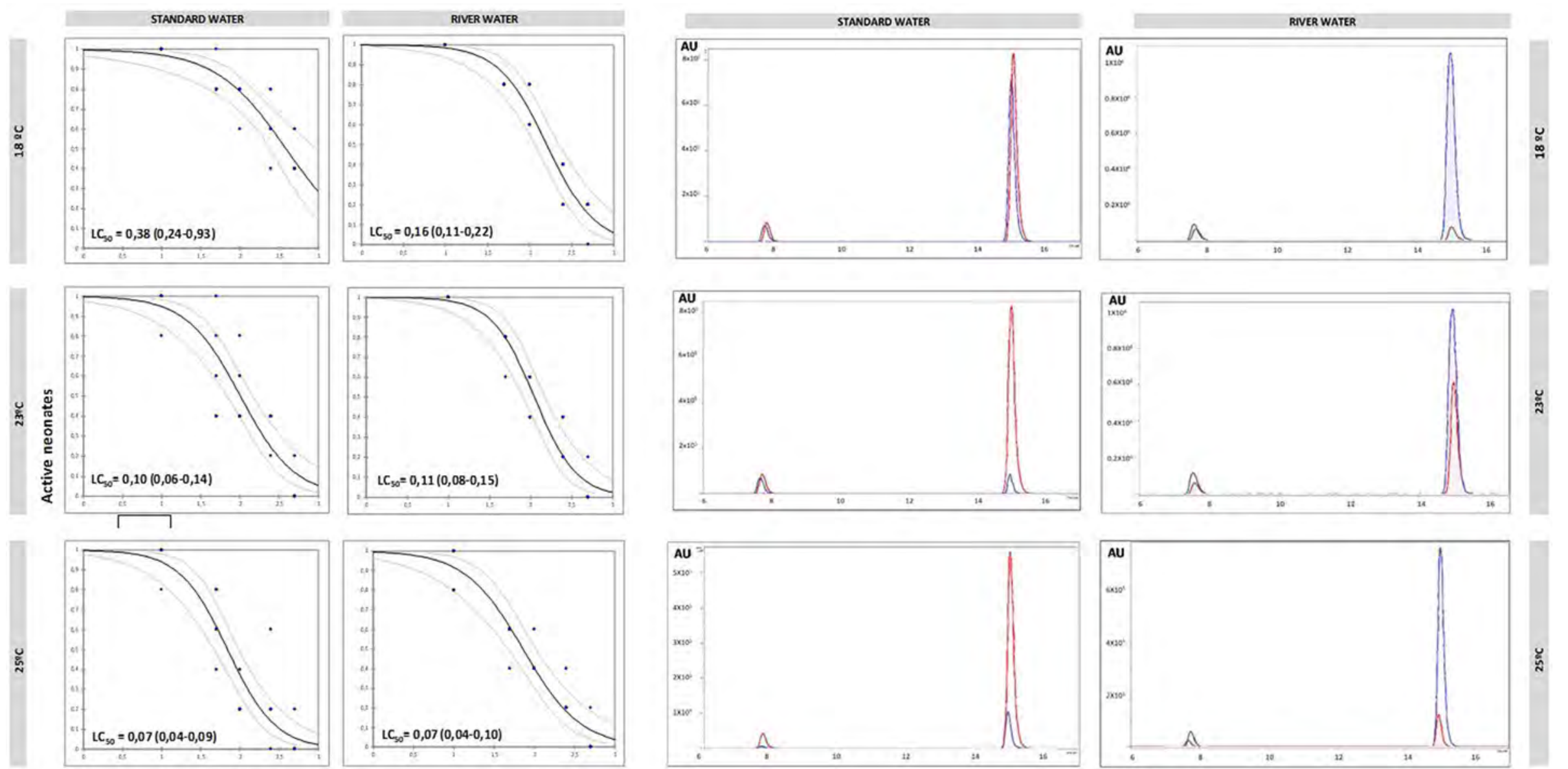

Log concentration $(\mathrm{mg} / \mathrm{L})$

Time (min)

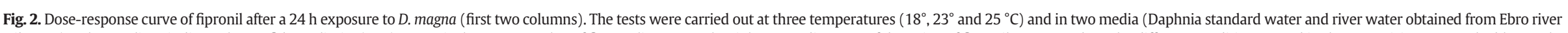

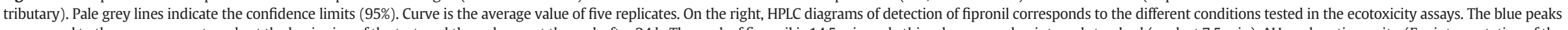

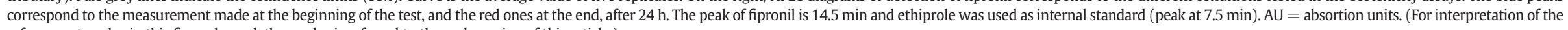
references to color in this figure legend, the reader is referred to the web version of this article.) 


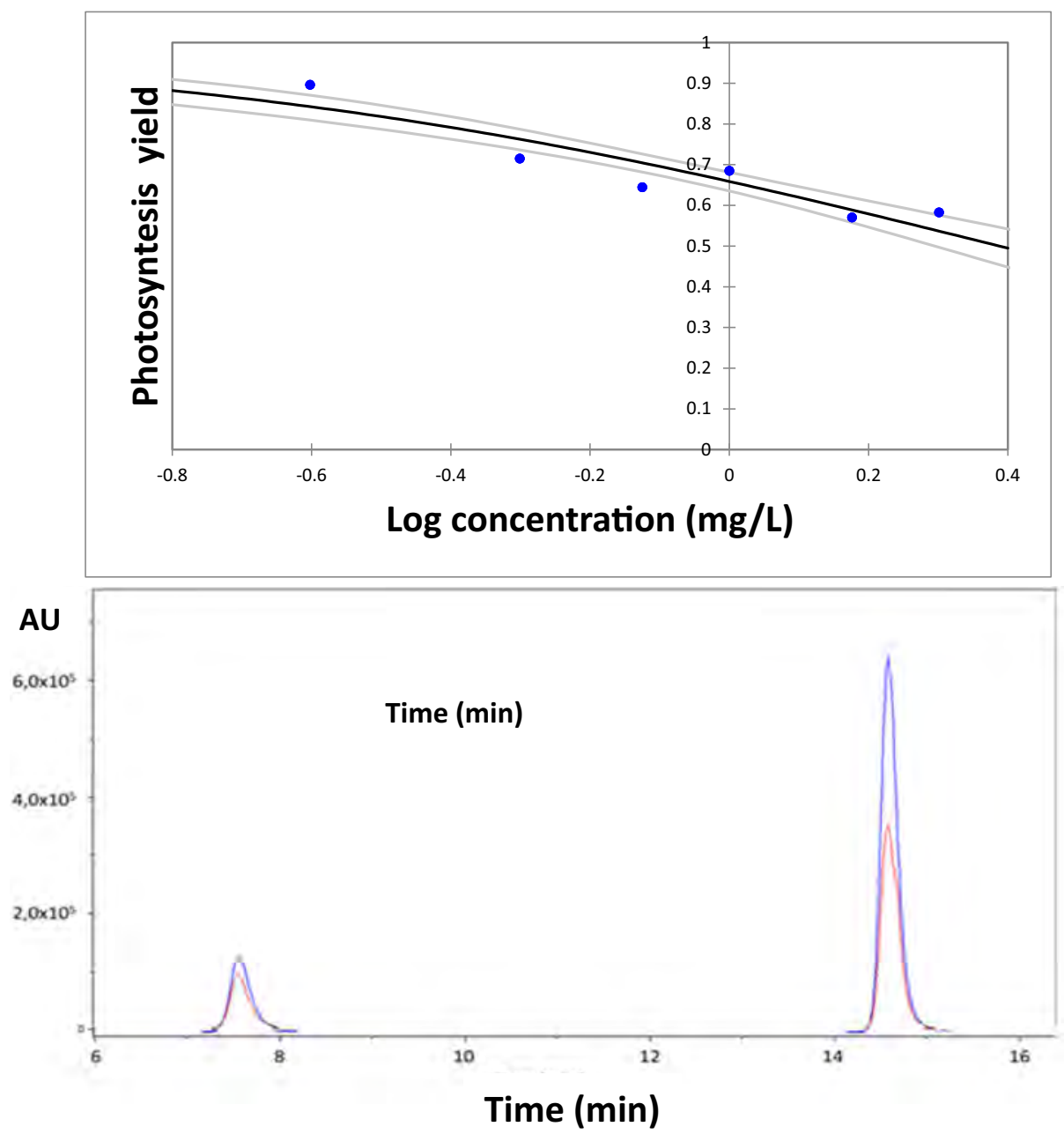

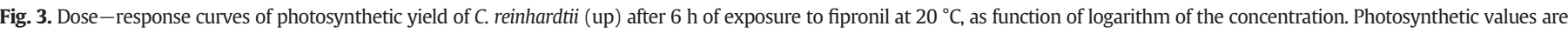

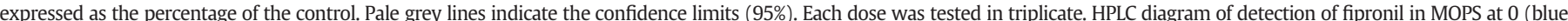
peak) and $6 \mathrm{~h}$ (red peak) under the same conditions as the ecotoxicity assays, can be seen down. The peak of fipronil is 14.5 min and ethiprole was used as internal standard (peak at

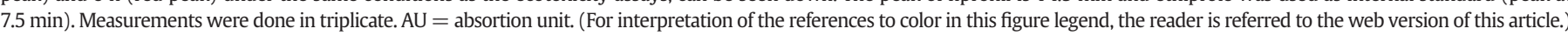

\subsection{Effects of fipronil on water and soil microorganisms}

\subsubsection{Effect of fipronil in microorganisms' metabolism}

There are hardly any differences in the ability of microorganisms to degrade the different carbon sources present in the EcoPlate, regardless of the presence of fipronil (Fig. 8, river water and soil microorganisms are shown in the first and second columns, respectively). Differences from control due to temperature are also very small (all $p$ values were between $0,08-0,9$ ).

Fipronil solubility was maintained throughout the 96-h assay in both solvents, river water and MOPS (See HPLC graphs, Fig. 9), although solubility fluctuated and increased with time in both media (central figure, Fig. 9).

\subsubsection{Genetic identification of microbial populations}

River microorganism sequencing comprised 165,548 total reads, of which 156,405 passed filter of quality (94.5\%). Each level of organisation was successfully sequenced: $>94 \%$ phyla, $65 \%$ family, $61.29 \%$ genus and $28.3 \%$ species. Soil microorganism sequencing involved 209,275 reads, of which 196,682 passed filter of quality (90\%). All levels of organisation were optimally sequenced ( $>95 \%$ ) except for genus (sequenced in $41 \%$ of microorganisms). The chart in Fig. 10 and Support information 2 show the per cent taxa abundance for the different taxonomic levels for water and soil microorganisms within each taxonomic level.
3.4.2.1. Water microorganisms. There were three predominant water bacteria phyla: Proteobacteria (41.19\%), Cyanobacteria (32.07\%) and Bacteroidetes (10.95\%). A small number of bacterial reads $(8.97 \%)$ could not be identified, indicating the extent of novel sequences in this study.

Proteobacteria can be classified in alpha, beta, gamma and delta families based on 16S rRNA. We found the four classes: Gammaproteobacteria (36.99\% of Proteobacteria, 14.25\% of the total taxa), Alphaproteobacteria (28.50\% of Proteobacteria; $10.98 \%$ of total taxa), Betaproteobacteria (19.91\% of Proteobacteria; $7.67 \%$ of total taxa) and Deltaproteobacteria (11.25\% of Proteobacteria; $4.33 \%$ of total taxa).

The most abundant order among Gammaproteobacteria was Xanthomonadales (34.32\% of Proteobacteria; $4.89 \%$ of total taxa) and the order Rhodobacterales was the predominant one among Alphaproteobacteria (53.05\% of the Alphaproteobacteria; $5.82 \%$ of total taxa).

Among Betaproteobacteria, the dominant order was Burkholderiales (69.46\% of the Betaproteobacteria; $5.33 \%$ of total taxa). Finally, Myxococcales was the predominant order $(48.97 \%$ of the Deltaproteobacteria; $2.12 \%$ of total taxa) among Deltaproteobacteria.

Virtually all Cyanobacteria members of our samples were from class Oscillatoriophycideae (91.33\% of Cyanobacteria reads; $27.40 \%$ of total taxa) and all the bacteria in this class are of the order Chroococcales. Beyond the order, it has been difficult to classify. 


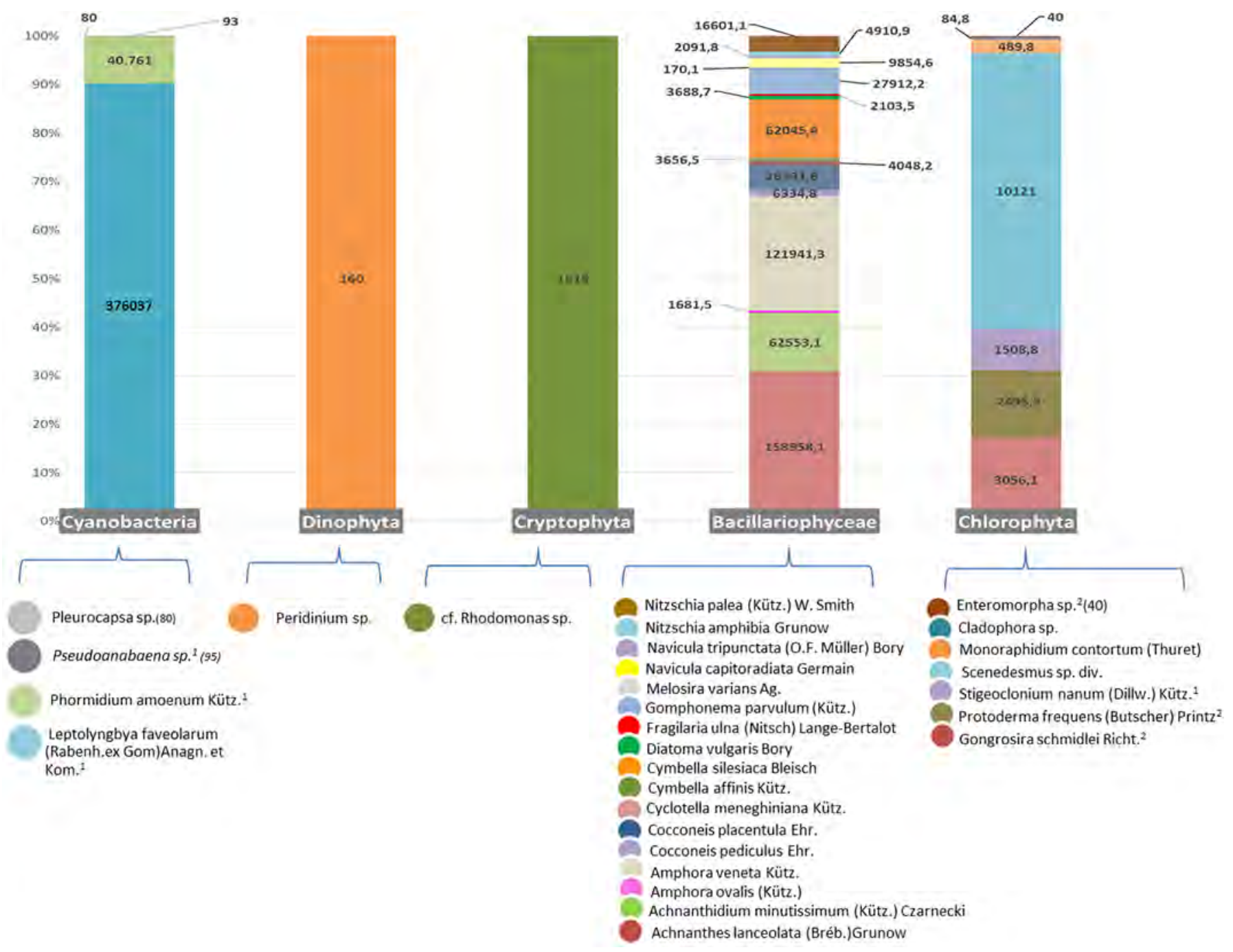

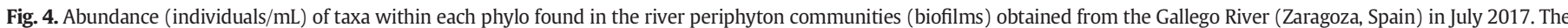
numbers are the average of 10 replicas. 11 ind. $=100$ pm length filament; 21 ind. = thallus with diameter of 1000 pm; others, 1 ind, $=1$ cell.

We found the class Sphingobacteriia as the most abundant among Bacteroidetes phylum (76.07\% of the Bacteroidetes; $7.79 \%$ of total reads).

3.4.2.2. Soil microorganisms. In soil samples, Proteobacteria were also the main bacterial phylum (79,91\%), followed distantly by Bacteroidetes (10.40\%) and Actinobacteria (6.77\%).

Gammaproteobacteria (44.63\% of Proteobacteria, $34.42 \%$ of the total taxa) was also the predominant Proteobacteria class, followed by Betaproteobacteria (24.36\% of Proteobacteria; $17.69 \%$ of total taxa), Alphaproteobacteria (21.58\% of Proteobacteria; $15.67 \%$ of total taxa) and Epsilonproteobacteria (8.92\% of Proteobacteria; $6.48 \%$ of total taxa).

Among the Gammaproteobacteria class, virtually all belonged to the order Pseudomonadales (98.80\% of Gammaproteobacteria, 32.03\% of the total taxa). All of those microorganisms belonged to the family Pseudomonadaceae and the genus Pseudomonas.

Betaproteobacteria was almost entirely comprised of the order Burkholderiales (96.45\% of Betaproteobacteria, $17.07 \%$ of the total taxa). The main family was Oxalobacteraceae $(80.26 \%$ of Burkholderiales, $13.7 \%$ of total reads), and among them, Janthinobacterium was the predominant genus $(91.23 \%$ of Oxalobacteraceae, $12.50 \%$ of total reads).

The main order of Alphaproteobacteria was Sphingomonadales (59.91\% of Alphaproteobacteria, 9,39\% of total reads), all of them from the family Sphingomonadaceae.
The class Sphingobacteriia predominated among Bacteroidetes (82.32\% of Bacteroidetes, $7.80 \%$ of total reads).

\section{Discussion}

Daphnia magna has the lower $\mathrm{LC}_{50}$ values among the organisms tested in this study, an expected outcome given the nature and mode of action of the fipronil, with an $\mathrm{LC}_{50}$ from 0.07 to $0.38 \mathrm{mg} / \mathrm{L}$. The river periphyton presented slightly higher values $\left(\mathrm{EC}_{50}\right.$ of $\left.0.74 \mathrm{mg} / \mathrm{L}\right)$, and the algae $C$. reinhardtii has the higher values of $\mathrm{LC}_{50}$ to fipronil $(2.44 \mathrm{mg} / \mathrm{L})$. The metabolism of river bacterial communities was not affected. Notably, as observed in the different experiments, fipronil solubility changed over time, at different temperatures and in different environments. Hence, these factors may differentially affect its toxicity depending on the organism on which it acts.

\subsection{Effect of fipronil on D. magna}

The short-term acute toxicity values of fipronil for D. magna in this study are in the range of those described previously: $\mathrm{LC}_{50}$ values from 0.08 to $0.19 \mathrm{mg} / \mathrm{L}$ (Hayasaka et al., 2012b; Iwafune et al., 2011; USEPA, 2000). Other closely related cladocerans, such as Daphnia pulex or Ceriodaphnia dubia, presented $\mathrm{LC}_{50}$ values in the same range, from $0.0156 \mathrm{mg} / \mathrm{L}$ to $0.51 \mathrm{mg} / \mathrm{L}$ (Stark and Vargas, 2005). Daphnids have a GABA receptor, albeit in a different conformation compared to 


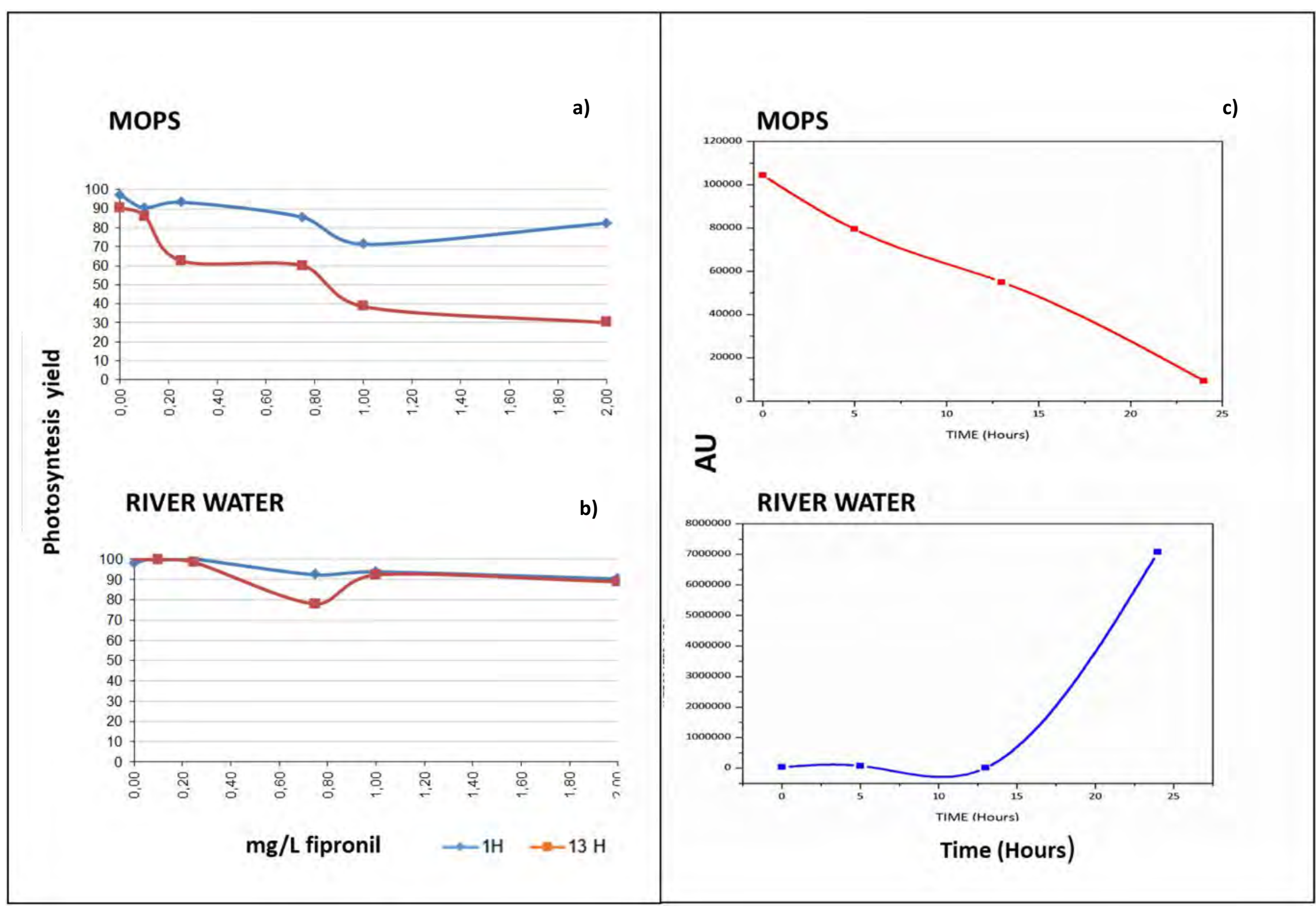

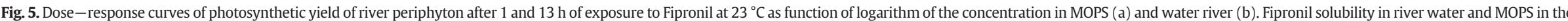
experimental conditions of periphyton communities assay can be seen in graph (c) where integrated peak area of HPLC analysis are represented. AU $=$ absortion units. 


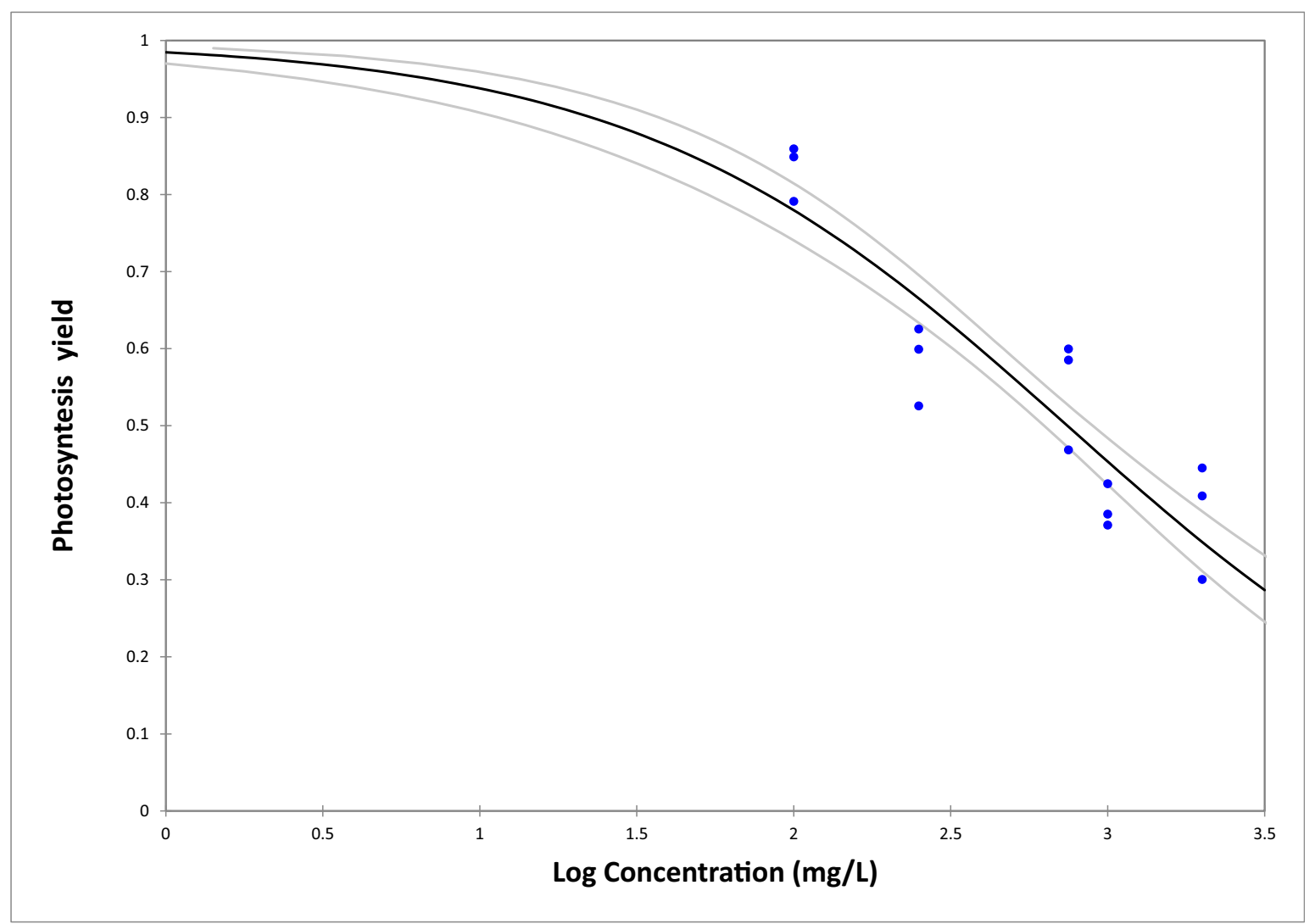

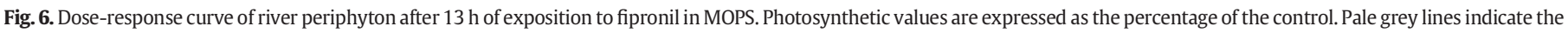
confidence limits (95\%). Each dose was measured in triplicate.

vertebrates (Jackel et al., 1994). Previous studies (Barry, 2002) have shown that cholinergic and GABAergic drugs modulate neckteeth development in $D$. pulex. The authors proposed that these chemicals modulate the release of neurohormones; mechanism of action may underscore the effect of fipronil in D. magna.

An increase in temperature enhanced fipronil toxicity in both synthetic and river water. A modulating effect of temperature on insecticide toxicity has been described for insects (Musser and Shelton, 2005; Srigiriraju et al., 2010). However, while organophosphates may exhibit enhanced toxicity as the temperature increases, pyrethroids have shown the opposite behaviour (Arthur, 1999; Athanassiou et al., 2008; Vayias et al., 2006; Kavallieratos et al., 2009). As far as we know, only one previous study examined the influence of temperature on fipronil and found that this insecticide presented biphasic behaviour in the

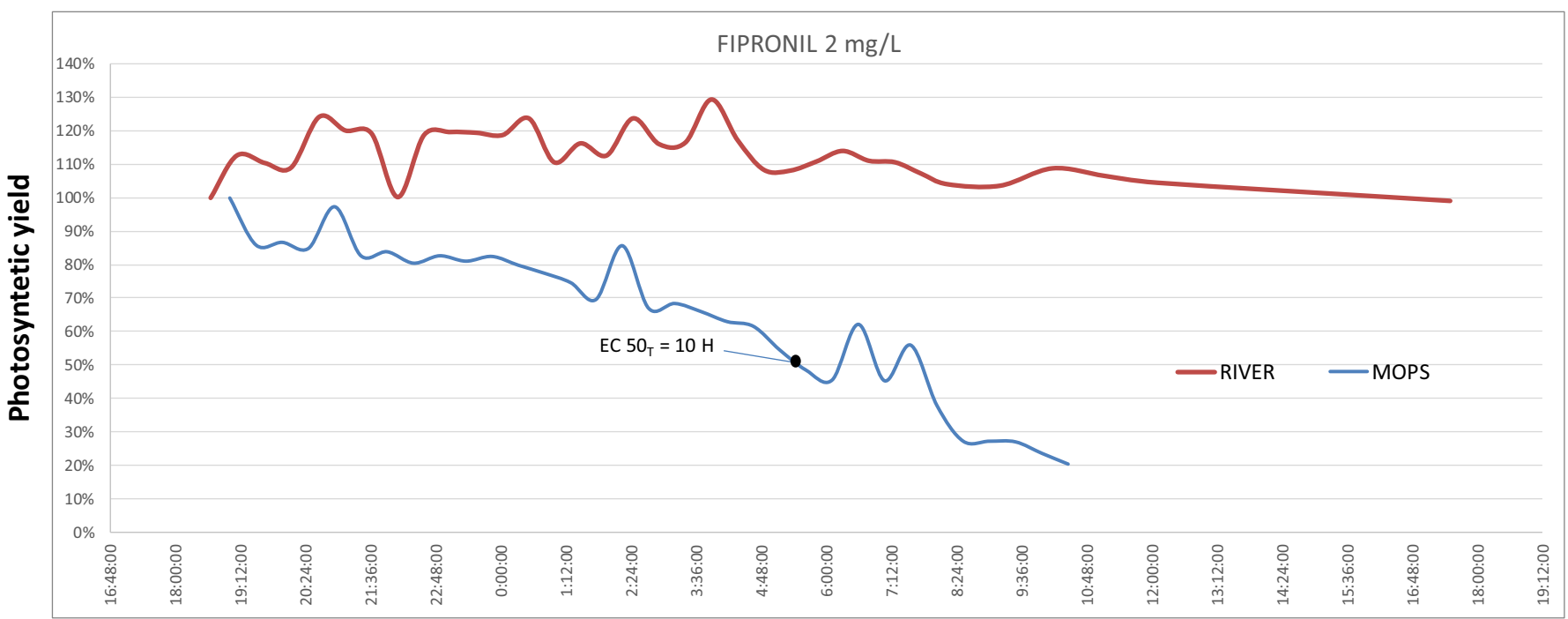

Time

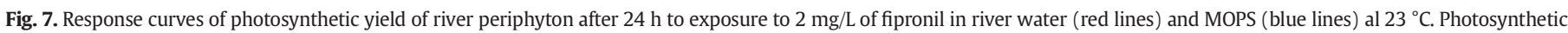
values are expressed as the percentage of the control. (For interpretation of the references to color in this figure legend, the reader is referred to the web version of this article.) 


\section{River microorganisms exposed to fipronil}

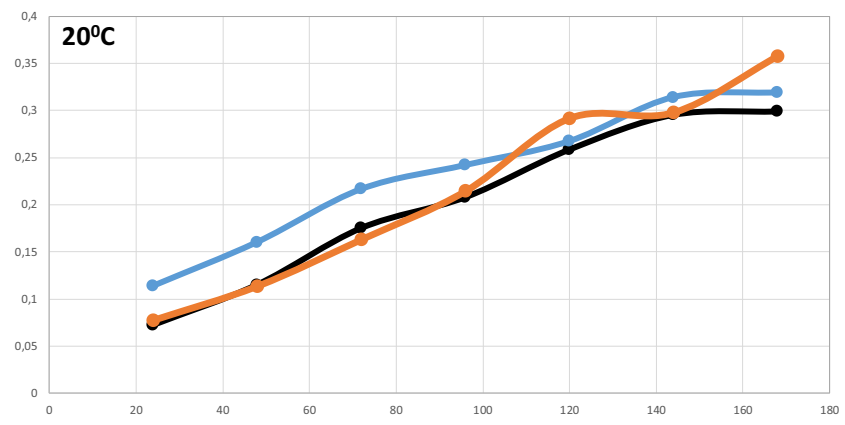

\section{Soil microorganisms exposed to fipronil}

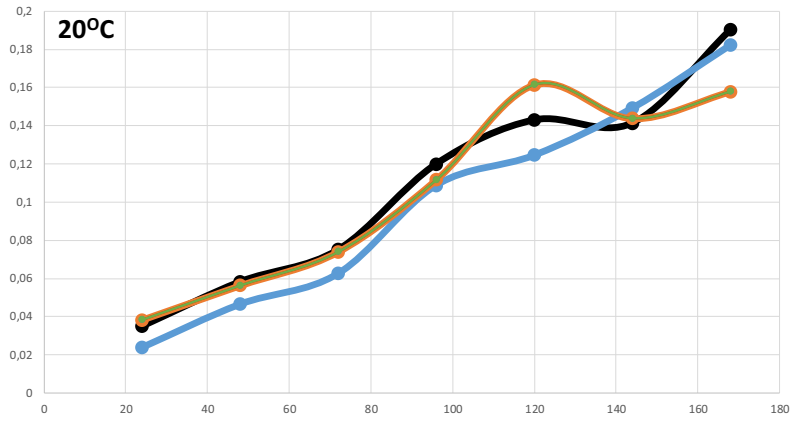

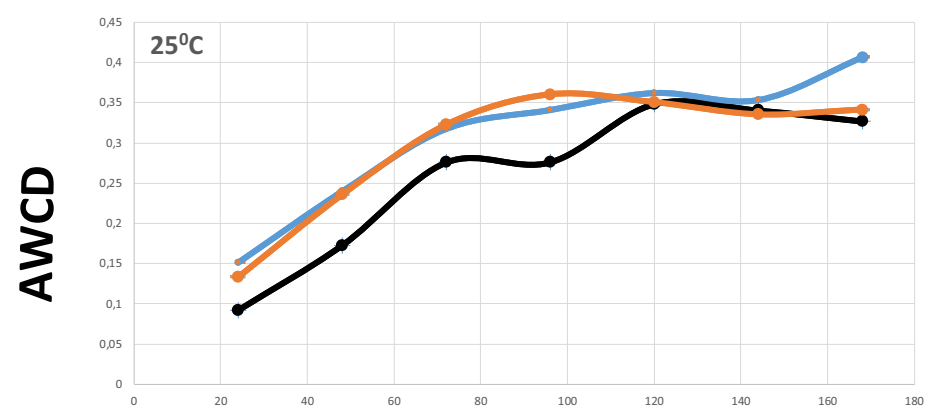
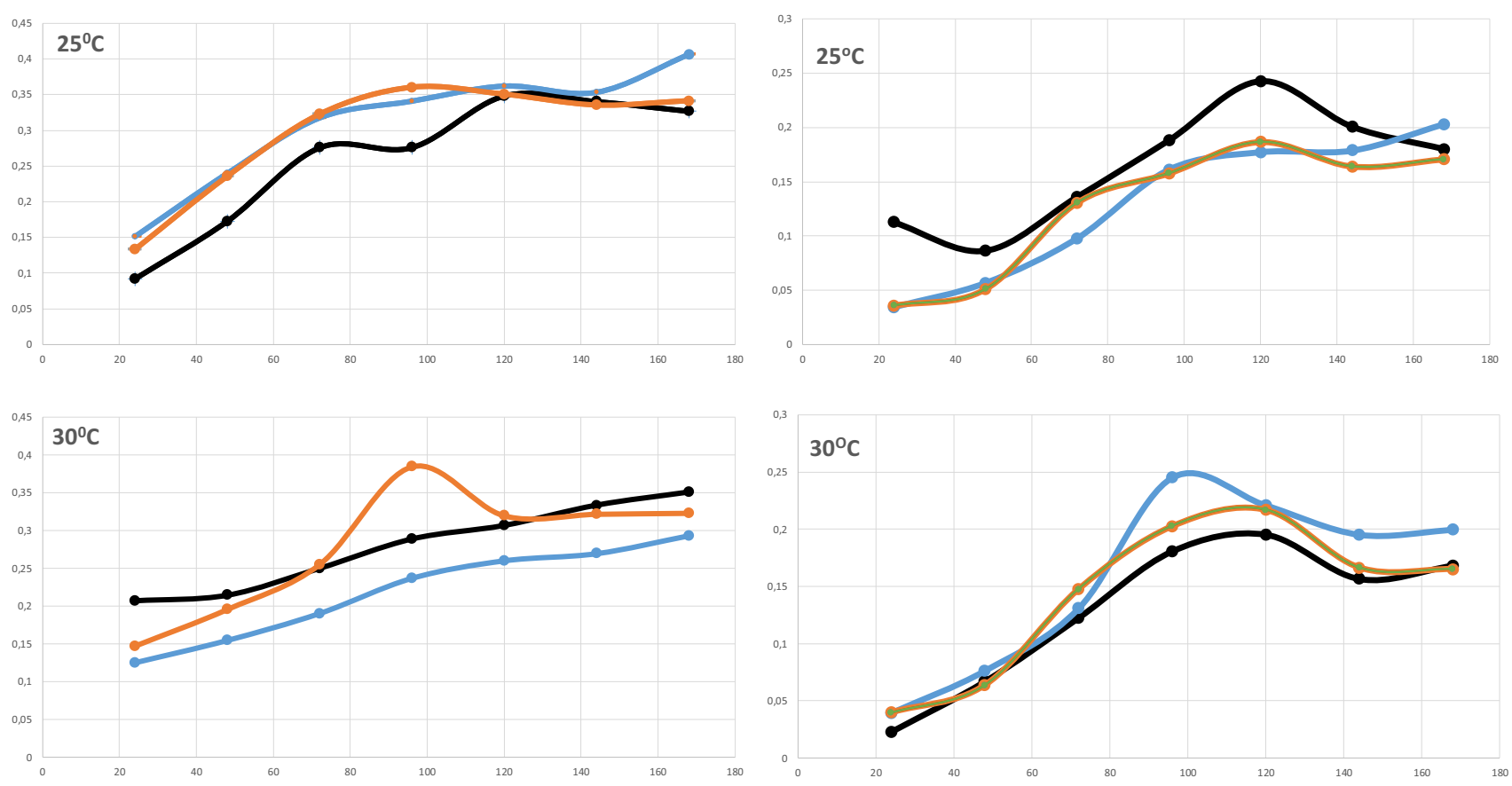

Time (hours)

-AWCD Control

AWCD 0,1 mg/L

$A W C D 1 \mathrm{mg} / \mathrm{L}$

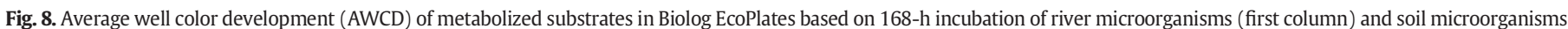

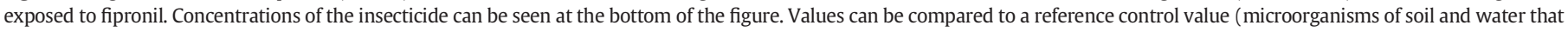
have not been treated with fipronil, only mineral water). Each point is the average value of three replicates.

heteroptera Apolygus lucorum: toxicity decreased from 15 to $20^{\circ} \mathrm{C}$ and increased from 20 to $35^{\circ} \mathrm{C}$ (Ma et al., 2012).

Fipronil is very stable in neutral aqueous $\mathrm{pH}$ solution at $18-25{ }^{\circ} \mathrm{C}$ (Bobe et al., 1998; Ramesh and Balasubramanian, 1999). In this study, its solubility increased in standard water and decreased in river water over $24 \mathrm{~h}$; these differences were less marked at $18{ }^{\circ} \mathrm{C}$ compared to the other temperatures. Fipronil solubility decreases considerably at higher salinities (Goff et al., 2017). This factor may explain its lower solubility in river water, which contains more dissolved solids and salts (Table 1 ). However, its toxicity in the standard medium and river water at 23 and $25^{\circ} \mathrm{C}$ was similar. Therefore, solubility - which also depends on the temperature - does not seem to play a key role in explaining the differences in toxicity. Temperature-related changes in toxicity likely rely on mechanisms other than changes on fipronil physicochemical characteristics, such as the metabolic activity of Daphnia. At $25^{\circ} \mathrm{C}$, Daphnia may present an accelerated life cycle so an increase in
Daphnia activity and feed consumption would lead to a consequent increase in toxicant intake (Betini et al., n.d.).

\subsection{Effect of fipronil on C. reinhardtii}

This study is the first to assess the short-term acute toxicity of fipronil on C. reinhardtii. The $\mathrm{EC}_{50}$ values are higher than those from previous studies on different algae. Studies on the marine phytoplankton Dunaliella tertiolecta resulted in an $\mathrm{EC}_{50}$ of $0.63 \mathrm{mg} / \mathrm{L}$ (Overmyer et al., 2007). The R- and S-fipronil enantiomers showed $\mathrm{EC}_{50}$ values of $0.29 \mathrm{mg} / \mathrm{L}$ and $1.50 \mathrm{mg} / \mathrm{L}$ for Scenedesmus obliguus (Qu et al., 2014). The United States Environmental Protection Agency (EPA's, 2007) has provided some ecotoxicity values of fipronil for diatoms like Navicula pelliculosa and Skeletonema costatum: 5-day EC $_{50}$ values of $0.12 \mathrm{mg} / \mathrm{L}$ and $>0.14 \mathrm{mg} / \mathrm{L}$, respectively. In addition, the green alga Selenastrum capricornutum showed a 5-day $\mathrm{EC}_{50} 0.14 \mathrm{mg} / \mathrm{L}$ and the blue-green alga 

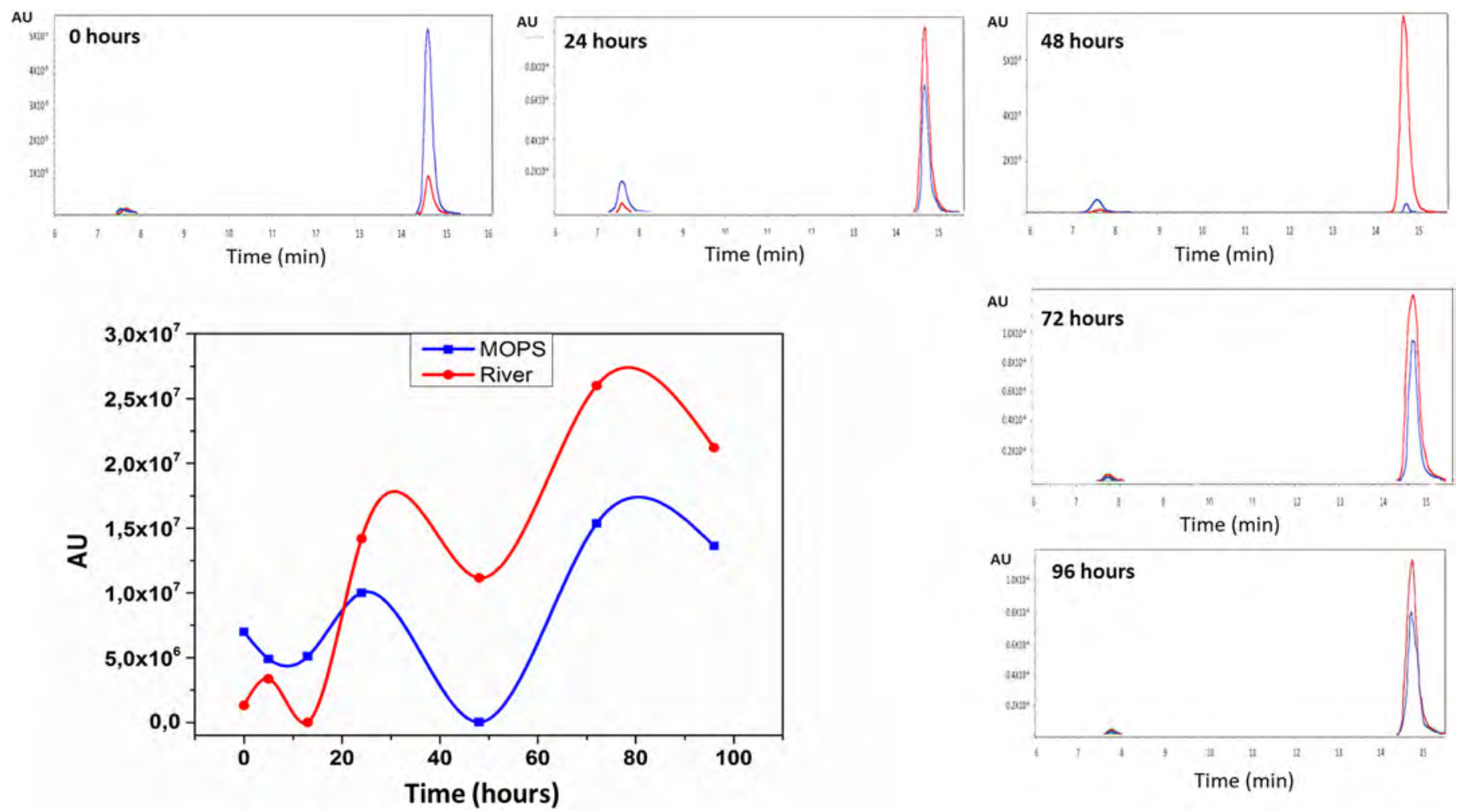

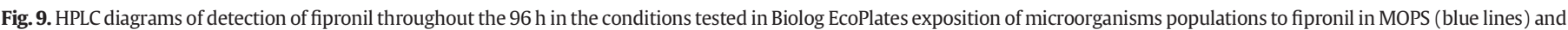

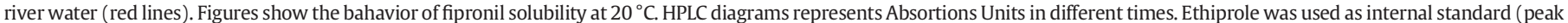

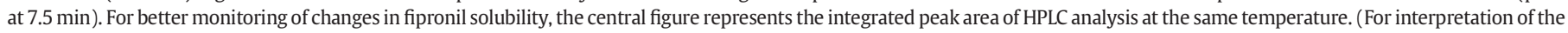
references to color in this figure legend, the reader is referred to the web version of this article.)

Anabaena flos-aquae presented an $\mathrm{EC}_{50}>0.17 \mathrm{mg} / \mathrm{L}$. All these studies were based on long-term exposure tests (several days). The use of a very specific endpoint, such as photosynthesis, rather than more integrative measures like growth, together with the acute short-term test approach, could explain the higher $\mathrm{EC}_{50}$ obtained in this study.

The fipronil mechanism of action on unicellular algae remains unknown. In the biosorption process, organic contaminants are absorbed at the surface of the cell wall (Qu et al., 2014), a phenomenon that may commence bioaccumulation. Hence, the insecticide may damage the functions or structures of the algal cell. For example, S. capricornutum exposed to carbofuran and diuron exhibits significantly reduced growth and suffer physiological (chlorophyll $a$ content) and morphological (complexity and cell size) changes (Mansano et al., 2017). In other cases, sublethal effects occur and although cell viability is not affected, pesticide exerted genotoxic effects (Martinez et al., 2015). However, members of the genus Chlamydomona have a complex cell wall that is formed by hydroxyproline-rich glycoprotein and crystalline layers (Voigt, 1988) that may act as a protective barrier (Sena et al., 2010) and thus explain their resistance to this pesticide. Regarding the differences in toxicity depending on the utilised media (river water or MOPS), the affinity of fipronil to organic matter or suspended solids, due to its high logKow values, may reduce its bioavailability for C. reinhardtii in river water (Table 1 ). This factor may underlie why we did not detect the effect of fipronil on the algae in this medium in any of the tested conditions. Modulation of freshwater ecotoxicology by the presence and quality of suspended and dissolved materials has been explained for Delgado-Moreno et al. (2011) for pyrethroids and for other pesticides in surface water (Hernandez-Antonio and Hansen, 2010; Knauer et al., 2017). Lajko et al. (1997) observed a suppression of the photosynthetic activity by respiration when the cells are incubated at temperatures $5-10{ }^{\circ} \mathrm{C}$ higher than the cultivation temperature, especially in short-term incubation periods. This photosynthesis suppression could explain why fipronil had no detectable changes on algae photosynthesis in MOPS at 25 or $30^{\circ} \mathrm{C}$.

\subsection{Effect of fipronil on periphyton}

This study showed that an insecticide such as fipronil may pose hazards to freshwater primary producers and decomposers. It has been demonstrated that herbicides (Paule et al., 2016; Chaumet et al., 2019; Dorigo et al., 2010) and their mixtures (Ham et al., 2014; Morin et al., 2012; Pesce et al., 2011) affect the microbial and photosynthetic fractions of the periphyton. However, as far as we know there is no information on the ecotoxicity effect of insecticides on biofilms.

The periphyton is a complex community composed of algae, bacteria, fungi, protozoa and invertebrates that develops on an underwater substratum (Seguin et al., 2001). Biofilms integrate the effects of environmental conditions over extended periods of time, so ecotoxicity results using periphyton provide more environmentally realistic results (Kraufvelin, 1998; Sabater et al., 2007). Periphyton, and particularly attached diatoms, are the dominant primary producers in small rivers (Schagerl and Donabaum, 1998) and are very sensitive to qualitative or quantitative environmental changes that have consequences for the whole trophic web (Denoyelles et al., 1982). Our results showed that fipronil affects the periphyton photosynthetic yield. These data indicate that at least the photosynthetic organisms among the biofilm community (e.g. diatoms, which are the most abundant and diverse in our samples) are affected by the insecticide.

Fipronil impacted photosynthetic yield at concentrations lower than those required by Chlamydomonas species, although the periphyton structure could be expected to show some resistance to the effect of fipronil. The sensitivity of biofilms to toxicants may depend on its thickness (Navarro et al., 2008), age, composition and velocity of the water flow (Sabater et al., 2002). In addition, other mechanisms of resistance, 


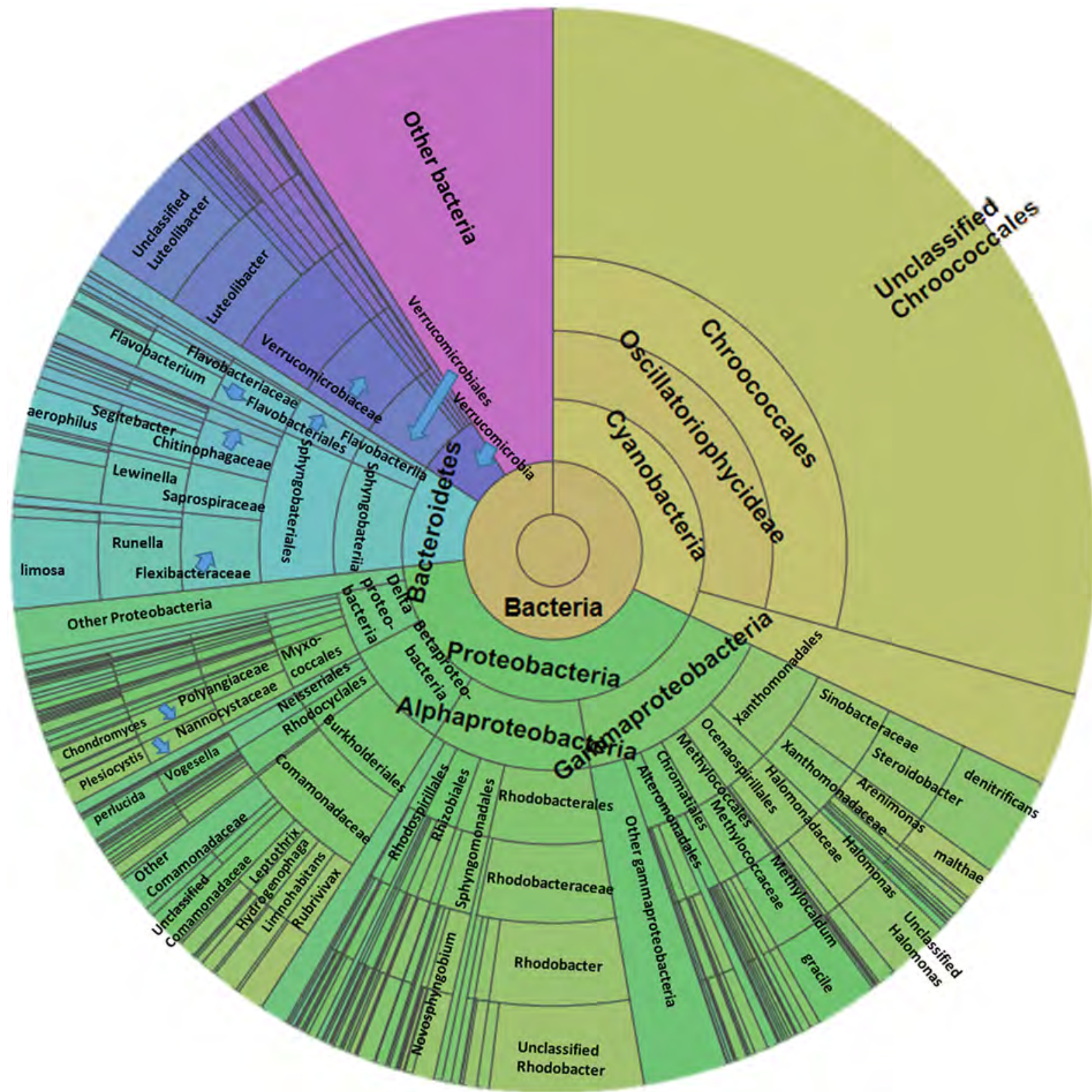

Fig. 10. Relative abundance of the river microbial main taxa within each taxonomic level. From inside the circle to outside: phylum, class, order, family, genus and species.

such as an exopolysaccharide (EPS) matrix, provide protection against pollutants like heavy metals (Nocelli et al., 2016), predation and environmental fluctuations (Headley et al., 1998; Miao et al., 2019; Manning et al., 2018). Although pesticide solubility is a key parameter for absorption of dissolved organics to biofilms, the lipophilic nature of a contaminant seems to also be an important factor (Headley et al., 1998). In addition, the longer exposure time (13 vs. $1 \mathrm{~h}$ ) and the flow velocity - which reduces the boundary layer and thus increases the uptake of toxicants in biofilms - may explain this apparently higher sensitivity of periphyton compared to $C$. reinhardtii.

Similar to C. reinhardtii, fipronil was more toxic in MOPS medium compared to river water. The mechanism is likely to be similar and related to the adsorption of insecticide to suspended organic matter in river water. A recent study found that organic matter attenuates the toxic effects of $\mathrm{CuO}$ nanoparticles to the microbial community in sediment biofilms (Miao et al., 2019). On the other hand, the solubility of fipronil in river water and in MOPS fluctuated over time, but it remained higher in MOPS compared to river water at all time points (Fig. 5c).

\subsection{Effect of fipronil on river and soil microbial community}

The metabolism of microbial community, under experimental conditions including different temperatures, was not affected by fipronil, as shown by the AWCD results. This can be explained by the bioavailability of fipronil but also by the taxa composition of the microbial communities.

While fipronil solubility oscillated during the experiment, it remained soluble in river water or MOPS (Fig. 9). However, mechanisms of adsorption to organic matter suspended in river samples could make fipronil less bioavailable for river bacteria (Peret et al., 2010).

Despite the physicochemical aspects of fipronil, the main factor for the lack of a pesticide effect is likely due to the microbial community biology. Community responses are extremely complex, and the literature commonly records both positive and negative responses of different bacteria to each pesticide (Ros et al., 2006; Lo, 2010; Itoh et al., 2014; Rouze et al., 2019). A study focused on the effect of low fipronil concentrations ( 50 and $5 \mu \mathrm{M}$ ) on Escherichia coli resulted in no lethality (Bhatti 
et al., 2019). Among the microbial community, those species sensitive to fipronil can be replaced during the experiment by survivors (Xia et al., 2013), a phenomenon that compensates for losses and prevents (or masks) changes to the metabolic pattern of the community as a whole. Likewise, literature showed that the presence of fipronil residues in the soil does not adversely affect abundance and activity of two rhizosphere bacterial strains, Staphylococcus arlettae and Bacillus thuringiensis (At et al., 2019). Maute et al. (2015) used Biolog plates to study the effect of the fipronil on microorganisms in Australian grassland and found that pesticide treatment seems to not affect the functional diversity of the bacterial community of this arid zone - although microorganisms present in the samples were not identified.

Bacteria can use fipronil as a source of carbon and biodegrade it, as it has been described to S. arlettae and B. thuringiensis (At et al., 2019), Acinetobacter calcoaceticus and Acinetobacter oleivorans (Uniyal et al., 2016b), Stenotrophomonas acidaminiphila (Uniyal et al., 2016a) and Paracoccus sp. (Kumar et al., 2012). Even E. coli (Bhatti et al., 2019) may use fipronil as carbon source. Moreover, previous studies have shown that predominant bacterial taxa in our samples are specialists for degradation of high molecular weight compounds, including pesticides. For example, Gammaproteobacteria were the most abundant in our river water samples. This class include important degraders of organic compounds and pesticides in water (Holmsgaard et al., 2017), soil (Paul et al., 2006; Newman et al., 2016) and sediments (Fang et al., 2014). In freshwater bacterial communities where Alphaproteobacteria predominant, there was no significant effect on bacterial community structure or composition after exposure to the fungicide tebuconazole (Pascault et al., 2014). Burkholderiales, the main order found in both the river and soil samples among Betaproteobacteria, can degrade a vast array of aromatic compounds (Thoetkiattikul et al., 2017), including insecticides such as chlorpyrifos in water (Ferrario et al., 2017) and soil (Kim and Ahn, 2009), as well as dimethoate, fenitrothion or malathion in soil (Kim and Ahn, 2009). Curiously, insecticide properties of Burkholderiales itself have been reported (Ruiu, 2015). The class Sphingobacteriia that dominated among Bacteroidetes in our soil samples contains bacteria that are also very active in the degradation of organic compounds (Bauer et al., 2006; Bissett et al., 2008). Sphingobacteriia members are also able to degrade benzene compounds (Li et al., 2012) and seem to be able to degrade the insecticide bifenthrin and absorb it as nutrition (Zhang et al., 2017).

Cyanobacteria, an important presence in our river samples, can metabolise methyl parathion from culture medium (Fioravante et al., 2010). However, when tests are performed using individual organisms, the sensitivity of Cyanobacteria to pesticides is inconclusive (Ma et al., 2006; Stratton and Corke, 1982; Sabater and Carrasco, 2001a; Sabater and Carrasco, 2001b). At the community level, the effect of phytosanitary products has been extensively studied in rice field, where insecticides seems to promote the growth and nitrogen-fixing activity of rice field native cyanobacteria (reviewed by Kaushik et al., 2019). Finally, Pseudomonas spp. were also very abundant among our soil microorganisms. These bacteria maintain their production of plant growth promoting substances in the rhizosphere, after fipronil exposition (Ahemad and Khan, 2011b). In addition these bacteria can degrade organophosphorus pesticide (Jariyal et al., 2018) and are tolerant to the insecticide dimethoate and the pesticide pentachlorophenol (Hassen et al., 2018).

\subsection{Environmental relevance}

Our results suggest that fipronil could affect different trophic levels of the river ecosystems and their complex network of communities of periphyton, algae, fungi, protozoa and invertebrates, many of them on the bottom or with important functions in freshwater food webs. For example, changes in herbivore-producer interactions were expected if fipronil affects primary producers (algae, periphyton) that would lead to a reduction in herbivorous invertebrate densities and a top-down impact on trophic cascades (Relyea and Hoverman, 2006). Interestingly, sometimes the result of the interaction can be different. For example, after the application of the insecticide deltamethrin, a phytoplankton bloom occurred due to the nutrients released by the decomposing herbivorous arthropods that were killed by the insecticide (Knapp et al., 2005). Changes in interspecific competition due to differential sensitivity of competitors to pesticides are also possible. Species that are more sensitive to the pesticide are eliminated and those that are more tolerant come to dominate, changing invertebrate community (Relyea, 2006; Fairchild and Eidt, 1993). For example, when moderate concentrations of insecticides are administered to communities containing both cladocerans (such as D. magna) and copepods, a dramatic decrease in the more sensitive cladocera species and a substantial increase in the abundance of copepods can be observed (vandenBrink, et al. 1996; Relyea, 2006).

Fipronil is present in freshwaters in the range of ng/L (Michel et al., 2016) up to $2 \mu \mathrm{g} / \mathrm{L}$ (Ensminger et al., 2013), concentrations lower than those capable of producing acute ecotoxicity as shown by our results.

However, Its bioaccumulation in different aquatic organisms has been reported (Qu et al., 2016; Dang et al., 2016; Lopez-Pacheco et al., 2019). In some cases, concentrations in animal tissues are similar to those found in river water. For example, in eel liver, fipronil has been found at a concentration of $19.91 \mathrm{ng} / \mathrm{g}$ (Michel et al., 2016). These findings suggest that, although the initial exposure of aquatic and terrestrial organisms to this insecticide does not reach ecotoxicity values, repeated and long-term exposure can lead to its bioaccumulation both in its original form and in its by-products. Hence, the chronic effects of fipronil toxicity cannot be ignored.

\section{Conclusions}

This study provided a comprehensive overview of the effect of the insecticide fipronil in a freshwater environment, considering its behaviour in different media and temperatures, and studying the effects not only on standard organisms but also on communities, including soil microorganisms. Fipronil affected the survival of $D$. magna, the photosynthetic activity of $C$. reinhardtii and the freshwater periphyton. However, soil and water bacterial communities identified through 16S rRNA gene sequencing were minimally affected by fipronil, probably due to the presence of specialist bacteria that can degrade pesticides. River water, in the case of $C$. reinhardtii and the freshwater periphyton, seems to interfere with fipronil toxicity, but this effect was not detected in the case of $D$. magna. Temperature increases the toxicity of the insecticide in the case of D. magna; this aspect must be considered in the context of expected global warming. Despite the fact that fipronil is present in freshwaters and soils in concentration ranges lower than the detected ecotoxicity values, these results highlight that toxic effects in the environment cannot be excluded given the prolonged presence of this insecticide in the environment and its bioaccumulation capacity.

Supplementary data to this article can be found online at https://doi. org/10.1016/j.scitotenv.2020.142820.

\section{CRediT authorship contribution statement}

María Rosa Pino-Otín: Conceptualization, Formal analysis, Funding acquisition, Investigation, Project administration, Resources, Supervision, Validation, Writing - original draft. Diego Ballestero: Data curation, Investigation, Methodology. Enrique Navarro: Resources, Data curation, Writing - review \& editing. Ana M. Mainar: Funding acquisition, Resources, Writing - review \& editing. Jonatan Val: Data curation, Investigation, Writing - review \& editing.

\section{Declaration of competing interest}

The authors declare that they have no known competing financial interests or personal relationships that could have appeared to influence the work reported in this paper. 


\section{Acknowledgements}

The authors thank the financial support of Gobierno de Aragón-FSE (Grupo GATHERS E39_17R) and Cátedra NOVALTIA.

\section{References}

Ahemad, M., Khan, M.S., 2011a. Effects of insecticides on plant-growth-promoting activities of phosphate solubilizing rhizobacterium Klebsiella sp strain PS19. Pestic. Biochem. Physiol. 100 (1), 51-56. https://doi.org/10.1016/j.pestbp.2011.02.004.

Ahemad, M., Khan, M.S., 2011b. Pseudomonas aeruginosa strain PS1 enhances growth parameters of greengram Vigna radiata (L.) Wilczek in insecticide-stressed soils. J. Pest. Sci. 84 (1), 123-131. https://doi.org/10.1007/s10340-010-0335-0.

Arthur, F.H., 1999. Effect of temperature on residual toxicity of cyfluthrin wettable powder. J. Econ. Entomol. 92 (3), 695-699. https://doi.org/10.1093/jee/92.3.695.

At, K., Karthikeyan, S., Thanga, V.S.G., 2019. Occurrence and microbial degradation of fipronil residues in tropical highland rhizosphere soils of Kerala, India. Soil Sediment Contam. 28 (4), 360-379. https://doi.org/10.1080/15320383.2019.1578336.

Athanassiou, C.G., Kavallieratos, N.G., Yiatilis, A.E., Vayias, B.J., Mavrotas, C.S., Tomanovic, Z., 2008. Influence of temperature and humidity on the efficacy of spinosad against four stored-grain beetle species. J. Insect Sci. 8.

Barry, M.J., 2002. Progress toward understanding the neurophysiological basis of predator-induced morphology in Daphnia pulex. Physiol. Biochem. Zool. 75 (2), 179-186. https://doi.org/10.1086/339389.

Bauer, M., Kube, M., Teeling, H., Richter, M., Lombardot, T., Allers, E., Wurdemann, C.A., Quast, C., Kuhl, H., Knaust, F., Woebken, D., Bischof, K., Mussmann, M., Choudhuri, J.V., Meyer, F., Reinhardt, R., Amann, R.I., Glockner, F.O., 2006. Whole genome analysis of the marine Bacteroidetes 'Gramella forsetii' reveals adaptations to degradation of polymeric organic matter. Environ. Microbiol. 8 (12), 2201-2213. https://doi.org/ 10.1111/j.1462-2920.2006.01152.x.

Bedient, P.B., Horsak, R.D., Schlenk, D., Hovinga, R.M., Pierson, J.D., 2005. Environmental impact of Fipronil to the Louisiana crawfish industry. Environ. Forensic 6 (3), 289-299. https://doi.org/10.1080/15275920500194530.

Beggel, S., Werner, I., Connon, R.E., Geist, J.P., 2012. Impacts of the phenylpyrazole insecticide fipronil on larval fish: time-series gene transcription responses in fathead minnow (Pimephales promelas) following short-term exposure. Sci. Total Environ. 426, 160-165. https://doi.org/10.1016/j.scitotenv.2012.04.005.

Betini, G. S., X. Q. Wang, T. Avgar, M. M. Guzzo, J. M. Fryxell. Food availability modulates temperature-dependent effects on growth, reproduction, and survival in Daphnia magna. Ecol. Evol. https://doi.org/10.1002/ece3.5925.

Bhatti, S., Satyanarayana, G.N.V., Patel, D.K., Satish, A., 2019. Bioaccumulation, biotransformation and toxic effect of fipronil in Escherichia coli. Chemosphere 231, 207-215. https://doi.org/10.1016/j.chemosphere.2019.05.124.

Bissett, A., Bowman, J.P., Burke, C.M., 2008. Flavobacterial response to organic pollution. Aquat. Microb. Ecol. 51 (1), 31-43. https://doi.org/10.3354/ame01174.

Bobe, A., Coste, C.M., Cooper, J.F., 1997. Factors influencing the adsorption of fipronil on soils. J. Agric. Food Chem. 45 (12), 4861-4865. https://doi.org/10.1021/jf970362z.

Bobe, A., Meallier, P., Cooper, J.F., Coste, C.M., 1998. Kinetics and mechanisms of abiotic degradation of fipronil (hydrolysis and photolysis). J. Agric. Food Chem. 46 (7), 2834-2839. https://doi.org/10.1021/jf970874d.

Caporaso, J.G., Lauber, C.L., Walters, W.A., Berg-Lyons, D., Lozupone, C.A., Turnbaugh, P.J., Fierer, N., Knight, R., 2011. Global patterns of 16S rRNA diversity at a depth of millions of sequences per sample. Proc. Natl. Acad. Sci. U. S. A. 108, 4516-4522. https://doi. org/10.1073/pnas.1000080107.

Caporaso, J.G., Lauber, C.L., Walters, W.A., Berg-Lyons, D., Huntley, J., Fierer, N., Owens, S.M., Betley, J., Fraser, L., Bauer, M., Gormley, N., Gilbert, J.A., Smith, G., Knight, R., 2012. Ultra-high-throughput microbial community analysis on the Illumina HiSeq and MiSeq platforms. ISME J. 6 (8), 1621-1624. https://doi.org/10.1038/ismej.2012.8.

Chaumet, B., Morin, S., Hourtane, O., Artigas, J., Delest, B., Eon, M., Mazzella, N., 2019. Flow conditions influence diuron toxicokinetics and toxicodynamics in freshwater biofilms. Sci. Total Environ. 652, 1242-1251. https://doi.org/10.1016/j. scitotenv.2018.10.265.

Consalvey, M., Perkins, R.G., Paterson, D.M., Underwood, G.J.C., 2005. Pam fluorescence: a beginners guide for benthic diatomists. Diatom Res. 20 (1), 1-22.

Dang, V.D., Kroll, K.J., Supowit, S.D., Halden, R.U., Denslow, N.D., 2016. Bioaccumulation of legacy and emerging organochlorine contaminants in Lumbriculus variegatus. Arch. Environ. Contam. Toxicol. 71 (1), 60-69. https://doi.org/ 10.1007/s00244-016-0264-X.

Delgado-Moreno, L., Lin, K., Veiga-Nascimento, R., Gan, J., 2011. Occurrence and toxicity of three classes of insecticides in water and sediment in two Southern California coastal watersheds. J. Agric. Food Chem. 59 (17), 9448-9456. https://doi.org/10.1021/ jf202049s.

Denoyelles, F., Kettle, W.D., Sinn, D.E., 1982. The responses of plankton communities in experimental PONDS to atrazine, the MOST heavily used pesticide in the UnitedStates. Ecology 63 (5), 1285-1293. https://doi.org/10.2307/1938856.

Dorigo, U., Berard, A., Rimet, F., Bouchez, A., Montuelle, B., 2010. In situ assessment of periphyton recovery in a river contaminated by pesticides. Aquat. Toxicol. 98 (4), 396-406. https://doi.org/10.1016/j.aquatox.2010.03.011.

Ensminger, M.P., Budd, R., Kelley, K.C., Goh, K.S., 2013. Pesticide occurrence and aquatic benchmark exceedances in urban surface waters and sediments in three urban areas of California, USA, 2008-2011. Environ. Monit. Assess. 185 (5), 3697-3710. https://doi.org/10.1007/s10661-012-2821-8.

EPA's, 2007. Report on the Environment: Science Report (Sab Review Draft). U.S. Environmental Protection Agency, Washington, D.C.
Fairchild, W.L., Eidt, D.C., 1993. Perturbation of the aquatic invertebrate community of acidic bog ponds by the insecticide fenitrothion. Arch. Environ. Contam. Toxicol. 25 (2 (Aug)), 170-183.

Fang, H., Cai, L., Yang, Y., Ju, F., Li, X.D., Yu, Y.L., Zhang, T., 2014. Metagenomic analysis reveals potential biodegradation pathways of persistent pesticides in freshwater and marine sediments. Sci. Total Environ. 470, 983-992. https://doi.org/10.1016/j. scitotenv.2013.10.076.

Ferrario, C., Pittino, F., Tagliaferri, I., Gandolfi, I., Bestetti, G., Azzoni, R.S., Diolaiuti, G., Franzetti, A., Ambrosini, R., Villa, S., 2017. Bacteria contribute to pesticide degradation in cryoconite holes in an Alpine glacier. Environ. Pollut. 230, 919-926. https://doi.org/ 10.1016/j.envpol.2017.07.039.

Fioravante, I.A., Barbosa, F.A.R., Augusti, R., Magalhaes, S.M.S., 2010. Removal of methyl parathion by cyanobacteria Microcystis novacekii under culture conditions. J. Environ. Monit. 12 (6), 1302-1306. https://doi.org/10.1039/b923288e.

Gan, J., Bondarenko, S., Oki, L., Haver, D., Li, J.X., 2012. Occurrence of fipronil and its biologically active derivatives in urban residential runoff. Environ. Sci. Technol. 46 (3), 1489-1495. https://doi.org/10.1021/es202904x.

Garland, J.L., Mills, A.L., 1991. Classification and characterization of heterotrophic microbial communities on the basis of patterns of community-level sole-carbon-source utilization. Appl. Environ. Microbiol. 57 (8), 2351-2359. https://doi.org/10.1128/ AEM.57.8.2351-2359.1991.

Garrison, A.W., 2011. An introduction to pesticide chirality and the consequences of stereoselectivity. Chiral Pesticides: Stereoselectivity and Its Consequences. 1085, pp. 1-7.

Goff, A.D., Saranjampour, P., Ryana, L.M., Hladik, M.L., Covi, J.A., Armbrust, K.L., Brander, S.M., 2017. The effects of fipronil and the photodegradation product fipronil desulfinyl on growth and gene expression in juvenile blue crabs, Callinectes sapidus, at different salinities. Aquat. Toxicol. 186, 96-104. https://doi.org/10.1016/j. aquatox.2017.02.027.

Gripp, H.S., Freitas, J.S., Almeida, E.A., Bisinoti, M.C., Moreira, A.B., 2017. Biochemical effects of fipronil and its metabolites on lipid peroxidation and enzymatic antioxidant defense in tadpoles (Eupemphix nattereri: Leiuperidae). Ecotoxicol. Environ. Saf. 136, 173-179. https://doi.org/10.1016/j.ecoenv.2016.10.027.

Gunasekara, A.S., Truong, T., Goh, K.S., Spurlock, F., Tjeerdema, R.S., 2007. Environmental fate and toxicology of fipronil. J. Pestic. Sci. 32 (3), 189-199. https://doi.org/ 10.1584/jpestics.RO7-02.

Ham, S.K., Morin, S., Pesce, S., Feurtet-Mazel, A., Moreira, A., Gonzalez, P., Mazzella, N., 2014. Environmental effects of realistic pesticide mixtures on natural biofilm communities with different exposure histories. Sci. Total Environ. 473, 496-506. https:// doi.org/10.1016/j.scitotenv.2013.12.060.

Hassen, W., Neifar, M., Cherif, H., Mahjoubi, M., Souissi, Y., Raddadi, N., Fava, F., Cherif, A., 2018. Assessment of genetic diversity and bioremediation potential of pseudomonads isolated from pesticide-contaminated artichoke farm soils. 3 Biotech 8 (6). https://doi.org/10.1007/s13205-018-1256-5.

Hayasaka, D., Korenaga, T., Suzuki, K., Saito, F., Sanchez-Bayo, F., Goka, K., 2012a. Cumulative ecological impacts of two successive annual treatments of imidacloprid and fipronil on aquatic communities of paddy mesocosms. Ecotoxicol. Environ. Saf. 80, 355-362. https://doi.org/10.1016/j.ecoenv.2012.04.004.

Hayasaka, D., Korenaga, T., Suzuki, K., Sanchez-Bayo, F., Goka, K., 2012b. Differences in susceptibility of five cladoceran species to two systemic insecticides, imidacloprid and fipronil. Ecotoxicology 21 (2), 421-427. https://doi.org/10.1007/s10646-0110802-2.

Headley, J.V., Gandrass, J., Kuballa, J., Peru, K.M., Gong, Y.L., 1998. Rates of sorption and partitioning of contaminants in river biofilm. Environ. Sci. Technol. 32 (24), 3968-3973. https://doi.org/10.1021/es9804991.

Hernandez-Antonio, A., Hansen, A.M., 2010. Role of suspended soil in the photodegradation of atrazine. In: Birkle, P., TorresAlvarado, I.S. (Eds.), WaterRock Interaction.

Holmsgaard, P.N., Dealtry, S., Dunon, V., Heuer, H., Hansen, L.H., Springael, D., Smalla, K., Riber, L., Sorensen, S.J., 2017. Response of the bacterial community in an onfarm biopurification system, to which diverse pesticides are introduced over an agricultural season. Environ. Pollut. 229, 854-862. https://doi.org/10.1016/j. envpol.2017.07.026.

Hussain, S., Hartley, C.J., Shettigar, M., Pandey, G., 2016. Bacterial biodegradation of neonicotinoid pesticides in soil and water systems. FEMS Microbiol. Lett. 363 (23). https://doi.org/10.1093/femsle/fnw252.

Itoh, H., Navarro, R., Takeshita, K., Tago, K., Hayatsu, M., Hori, T., Kikuchi, Y., 2014. Bacterial population succession and adaptation affected by insecticide application and soil spraying history. Front. Microbiol. 5. https://doi.org/10.3389/fmicb.2014.00457.

Iwafune, T., Yokoyama, A., Nagai, T., Horio, T., 2011. Evaluation of the risk of mixtures of paddy insecticides and their transformation products to aquatic organisms in the Sakura river, Japan. Environ. Toxicol. Chem. 30 (8), 1834-1842. https://doi.org/ 10.1002/etc.569.

Jackel, C., Krenz, W.D., Nagy, F., 1994. Bicuculline/baclofen-insensitive GABA response in crustacean neurons in culture. J. Exp. Biol. 191, 167-193.

Jariyal, M., Jindal, V., Mandal, K., Gupta, V.K., Singh, B., 2018. Bioremediation of organophosphorus pesticide phorate in soil by microbial consortia. Ecotoxicol. Environ. Saf. 159, 310-316. https://doi.org/10.1016/j.ecoenv.2018.04.063.

Kaushik, M.S., Kumar, A., Abraham, G., Dash, N.P., Singh, P.K., 2019. Field evaluations of agrochemical toxicity to cyanobacteria in rice field ecosystem: a review. J. Appl. Phycol. 31 (1), 471-489. https://doi.org/10.1007/s10811-018-1559-2.

Kavallieratos, N.G., Athanassiou, C.G., Vayias, B.J., Mihail, S.B., Tomanovic, Z., 2009. Insecticidal efficacy of abamectin against three stored-product insect pests: influence of dose rate, temperature, commodity, and exposure interval. J. Econ. Entomol. 102 (3), 1352-1359. https://doi.org/10.1603/029.102.0363. 
Khan, S., Jan, M.H., Kumar, D., Telang, A.G., 2015. Firpronil induced spermotoxicity is associated with oxidative stress, DNA damage and apoptosis in male rats. Pestic. Biochem. Physiol. 124, 8-14. https://doi.org/10.1016/j.pestbp.2015.03.010.

Kiljanek, T., Niewladowska, M., Posyniak, A., 2016. Pesticide poisoning of honeybees: a review of symptoms, incident classification, and causes of poisoning. J. Apicult. Sci. 60 (2), 5-24.

Kim, J.R., Ahn, Y.J., 2009. Identification and characterization of chlorpyrifos-methyl and 3,5,6-trichloro-2-pyridinol degrading Burkholderia sp strain KR100. Biodegradation 20 (4), 487-497. https://doi.org/10.1007/s10532-008-9238-7.

Kitulagodage, M., Isanhart, J., Buttemer, W.A., Hooper, M.J., Astheimer, L.B., 2011. Fipronil toxicity in northern bobwhite quail Colinus virginianus: reduced feeding behaviour and sulfone metabolite formation. Chemosphere 83 (4), 524-530. https://doi.org/ 10.1016/j.chemosphere.2010.12.057.

Knapp, C.W., et al., 2005. Response of water column microbial communities to sudden exposure to deltamethrin in aquatic mesocosms. FEMS Microbiol. Ecol. 54 (1 (Sep)), 157-165. https://doi.org/10.1016/j.femsec.2005.03.004.

Knauer, K., Homazava, N., Junghans, M., Werner, I., 2017. The influence of particles on bioavailability and toxicity of pesticides in surface water. Integr. Environ. Assess. Manag. 13 (4), 585-600. https://doi.org/10.1002/ieam.1867.

Kraufvelin, P., 1998. Model ecosystem replicability challenged by the "soft" reality of a hard bottom mesocosm. J. Exp. Mar. Biol. Ecol. 222 (1-2), 247-267. https://doi.org/ 10.1016/s0022-0981(97)00143-3.

Kumar, R., Singh, B., Gupta, V.K., 2012. Biodegradation of fipronil by Paracoccus sp in different types of soil. Bull. Environ. Contam. Toxicol. 88 (5), 781-787. https://doi.org/ 10.1007/s00128-012-0578-y.

Lajko, F., Kadioglu, A., Borbely, G., Garab, G., 1997. Competition between the photosynthetic and the (chloro)respiratory electron transport chains in cyanobacteria, green algae and higher plants. Effect of heat stress. Photosynthetica 33 (2), 217-226. https://doi.org/10.1023/a:1022160213152.

Li, H., Zhang, Q., Wang, X.L., Ma, X.Y., Lin, K.F., Liu, Y.D., Gu, J.D., Lu, S.G., Shi, L., Lu, Q., Shen, T.T., 2012. Biodegradation of benzene homologues in contaminated sediment of the East China Sea. Bioresour. Technol. 124, 129-136. https://doi.org/10.1016/j. biortech.2012.08.033.

Liu, T.T., Wang, P., Lu, Y.L., Zhou, G.X., Diao, J.L., Zhou, Z.Q., 2012. Enantioselective bioaccumulation of soil-associated fipronil enantiomers in Tubifex tubifex. J. Hazard. Mater. 219, 50-56. https://doi.org/10.1016/j.jhazmat.2012.03.042.

Lo, C.C., 2010. Effect of pesticides on soil microbial community. J. Environ. Sci. Health B Pestic. Food Contam. Agric. Wastes 45 (5), 348-359. https://doi.org/10.1080/ 03601231003799804.

Lopez-Pacheco, I.Y., Silva-Nunez, A., Salinas-Salazar, C., Arevalo-Gallegos, A., LizarazoHolguin, L.A., Barcelo, D., Iqbal, H.M.N., Parra-Saldivar, R., 2019. Anthropogenic contaminants of high concern: existence in water resources and their adverse effects. Sci. Total Environ. 690, 1068-1088. https://doi.org/10.1016/j.scitotenv.2019.07.052.

Lourenco, C.T., Carvalho, S.M., Malaspina, O., Nocelli, R.C.F., 2012. Oral toxicity of Fipronil insecticide against the stingless bee Melipona scutellaris (Latreille, 1811). Bull. Environ. Contam. Toxicol. 89 (4), 921-924. https://doi.org/10.1007/s00128-012-0773-X.

Ma, J.Y., Lu, N.H., Qin, W.D., Xu, R.F., Wang, Y.B., Chen, X.N., 2006. Differential responses of eight cyanobacterial and green algal species, to carbamate insecticides. Ecotoxicol. Environ. Saf. 63 (2), 268-274. https://doi.org/10.1016/j.ecoenv.2004.12.002.

Ma, Y.H., Gao, Z.L., Dang, Z.H., Li, Y.F., Pan, W.L., 2012. Effect of temperature on the toxicity of several insecticides to Apolygus lucorum (Heteroptera: Miridae). J. Pestic. Sci. 37 (2), 135-139. https://doi.org/10.1584/jpestics.D11-013.

Manning, D.W.P., Rosemond, A.D., Gulis, V., Benstead, J.P., Kominoski, J.S., 2018. Nutrients and temperature additively increase stream microbial respiration. Glob. Chang. Biol. 24 (1), E233-E247. https://doi.org/10.1111/gcb.13906.

Mansano, A.S., Moreira, R.A., Dornfeld, H.C., Freitas, E.C., Vieira, E.M., Sarmento, H., Rocha, O., Seleghim, M.H.R., 2017. Effects of diuron and carbofuran and their mixtures on the microalgae Raphidocelis subcapitata. Ecotoxicol. Environ. Saf. 142, 312-321. https:// doi.org/10.1016/j.ecoenv.2017.04.024.

Martinez, R.S., Di Marzio, W.D., Saenz, M., 2015. Genotoxic effects of commercial formulations of Chlorpyrifos and Tebuconazole on green algae. Ecotoxicology 24 (1), 45-54. https://doi.org/10.1007/s10646-014-1353-0.

Maruya, K.A., Dodder, N.G., Sengupta, A., Smith, D.J., Lyons, J.M., Heil, A.T., Drewes, J.E., 2016. Multimedia screening of contaminants of emerging concern (CECS) in coastal urban watersheds in southern California (USA). Environ. Toxicol. Chem. 35 (8), 1986-1994. https://doi.org/10.1002/etc.3348.

Maute, K., French, K., Bull, C.M., Story, P., Hose, G., 2015. Current insecticide treatments used in locust control have less of a short-term impact on Australian arid-zone reptile communities than does temporal variation. Wildl. Res. 42 (1), 50-59. https://doi.org/ 10.1071/wr14194.

Mianjy, J.G., Niknafs, B.N., 2013. Photodegradation of fipronil in natural water by high intensity UV light under laboratory conditions. Asian J. Chem. 25 (4), 2284-2288. https://doi.org/10.14233/ajchem.2013.13994.

Miao, L.Z., Wang, P.F., Hou, J., Yao, Y., Liu, Z.L., Liu, S.Q., 2019. Low concentrations of copper oxide nanoparticles alter microbial community structure and function of sediment biofilms. Sci. Total Environ. 653, 705-713. https://doi.org/10.1016/ j.scitotenv.2018.10.354.

Michel, N., Freese, M., Brinkmann, M., Pohlmann, J.D., Hollert, H., Kammann, U., Haarich, M., Theobald, N., Gerwinski, W., Rotard, W., Hanel, R., 2016. Fipronil and two of its transformation products in water and European eel from the river Elbe. Sci. Total Environ. 568, 171-179. https://doi.org/10.1016/j.scitotenv.2016.05.210.

Møhlenberg, F., Petersen, S., Gustavsson, K., Lauridsen, T., Friberg, N., 2001. Mesocosm experiment sin the approval procedures for pesticides - a literature study on effects of mesocosm characteristics and validity of extra- polation methods to protect sensitives pecies. Pesticides Research 56. Danish Environmental Protection Agency, Copenhagen.
Morin, S., Pesce, S., Kim-Tiam, S., Libert, X., Coquery, M., Mazzella, N., 2012. Use of polar organic chemical integrative samplers to assess the effects of chronic pesticide exposure on biofilms. Ecotoxicology 21 (5), 1570-1580. https://doi.org/10.1007/s10646012-0910-7.

Muniz, S., Lacarta, J., Pata, M.P., Jimenez, J.J., Navarro, E., 2014. Analysis of the diversity of substrate utilisation of soil bacteria exposed to cd and earthworm activity using generalised additive models. PLoS One 9 (1). https://doi.org/10.1371/journal. pone.0085057.

Musser, F.R., Shelton, A.M., 2005. The influence of post-exposure temperature on the toxicity of insecticides to Ostrinia nubilalis (Lepidoptera: Crambidae). Pest Manag. Sci. 61 (5), 508-510. https://doi.org/10.1002/ps.998.

Navarro, E., Guasch, H., Sabater, S., 2002. Use of microbenthic algal communities in ecotoxicological tests for the assessment of water quality: the Ter river case study. J. Appl. Phycol. 14 (1), 41-48. https://doi.org/10.1023/a:1015242301451.

Navarro, E., Robinson, C.T., Behra, R., 2008. Increased tolerance to ultraviolet radiation (UVR) and cotolerance to cadmium in UVR-acclimatized freshwater periphyton. Limnol. Oceanogr. 53 (3), 1149-1158. https://doi.org/10.4319/lo.2008.53.3.1149.

Newman, M.M., Hoilett, N., Lorenz, N., Dick, R.P., Liles, M.R., Ramsier, C., Kloepper, J.W., 2016. Glyphosate effects on soil rhizosphere-associated bacterial communities. Sci. Total Environ. 543, 155-160. https://doi.org/10.1016/j.scitotenv.2015.11.008.

Nocelli, N., Bogino, P.C., Banchio, E., Giordano, W., 2016. Roles of extracellular polysaccharides and biofilm formation in heavy metal resistance of rhizobia. Materials 9 (6). https://doi.org/10.3390/ma9060418.

OECD, 2004. Test No. 202: Daphnia sp. Acute Immobilisation Test, OECD Guidelines for the Testing of Chemicals, Section 2. OECD Publishing, Paris https://doi.org/10.1787/ 9789264069947-en.

de Oliveira, P.R., Bechara, G.H., Denardi, S.E., Oliveira, R.J., Mathias, M.I.C., 2012. Cytotoxicity of fipronil on mice liver cells. Microsc. Res. Tech. 75 (1), 28-35. https://doi.org/ 10.1002/jemt.21018.

Overmyer, J.P., Rouse, D.R., Avants, J.K., Garrison, A.W., Delorenzo, M.E., Chung, K.W., Key, P.B., Wilson, W.A., Black, M.C., 2007. Toxicity of fipronil and its enantiomers to marine and freshwater non-targets. J. Environ. Sci. Health B Pestic. Food Contam. Agric Wastes 42 (5), 471-480. https://doi.org/10.1080/03601230701391823.

Pascault, N., Roux, S., Artigas, J., Pesce, S., Leloup, J., Tadonleke, R.D., Debroas, D., Bouchez, A., Humbert, J.F., 2014. A high-throughput sequencing ecotoxicology study of freshwater bacterial communities and their responses to tebuconazole. FEMS Microbiol. Ecol. 90 (3), 563-574. https://doi.org/10.1111/1574-6941.12416.

Paul, D., Pandey, G., Meier, C., van der Meer, J.R., Jain, R.K., 2006. Bacterial community structure of a pesticide-contaminated site and assessment of changes induced in community structure during bioremediation. FEMS Microbiol. Ecol. 57 (1) 116-127. https://doi.org/10.1111/j.1574-6941.2006.00103.x.

Paule, A., Roubeix, V., Swerhone, G.D.W., Roy, J., Lauga, B., Duran, R., Delmas, F., Paul, E., Rols, J.L., Lawrence, J.R., 2016. Comparative responses of river biofilms at the community level to common organic solvent and herbicide exposure. Environ. Sci. Pollut. Res. 23 (5), 4282-4293. https://doi.org/10.1007/s11356-015-5141-z.

Peret, A.M., Oliveira, L.F., Bianchini, I., Seleghim, M.H.R., Peret, A.C., Mozeto, A.A., 2010. Dynamics of fipronil in Oleo Lagoon in Jatai Ecological Station, Sao Paulo-Brazil. Chemosphere 78 (10), 1225-1229. https://doi.org/10.1016/j.chemosphere.2009.12.060.

Pesce, S., Morin, S., Lissalde, S., Montuelle, B., Mazzella, N., 2011. Combining polar organic chemical integrative samplers (POCIS) with toxicity testing to evaluate pesticide mixture effects on natural phototrophic biofilms. Environ. Pollut. 159 (3), 735-741. https://doi.org/10.1016/j.envpol.2010.11.034.

Peveling, R., Demba, S.A., 2003. Toxicity and pathogenicity of Metarhizium anisopliae var. acridum (Deuteromycotina, Hyphomycetes) and fipronil to the fringe-toed lizard Acanthodactylus dumerili (Squamata: Lacertidae). Environ. Toxicol. Chem. 22 (7), 1437-1447. https://doi.org/10.1897/1551-5028(2003)22<1437:tapoma>2.0.co;2.

Pino, M.R., Muniz, S., Val, J., Navarro, E., 2016. Phytotoxicity of 15 common pharmaceuticals on the germination of Lactuca sativa and photosynthesis of Chlamydomonas reinhardtii. Environ. Sci. Pollut. Res. 23 (22), 22530-22541. https://doi.org/10.1007/ s11356-016-7446-y.

Pino-Otin, M.R., Ballestero, D., Navarro, E., Gonzalez-Coloma, A., Val, J., Mainar, A.M., 2019a. Ecotoxicity of a novel biopesticide from Artemisia absinthium on nontarget aquatic organisms. Chemosphere 216, 131-146. https://doi.org/10.1016/ j.chemosphere.2018.09.071.

Pino-Otin, M.R., Val, J., Ballestero, D., Navarro, E., Sanchez, E., Gonzalez-Coloma, A., Mainar, A.M., 2019b. Ecotoxicity of a new biopesticide produced by Lavandula luisieri on nontarget soil organisms from different trophic levels. Sci. Total Environ. 671, 83-93. https://doi.org/10.1016/j.scitotenv.2019.03.293.

Pino-Otin, M.R., Val, J., Ballestero, D., Navarro, E., Sanchez, E., Mainar, A.M., 2019c. Impact of Artemisia absinthium hydrolate extracts with nematicidal activity on non-target soil organisms of different trophic levels. Ecotoxicol. Environ. Saf. 180, 565-574. https://doi.org/10.1016/j.ecoenv.2019.05.055.

Pohland, B., 2009. In: Owen, B. (Ed.), TAS Technical Bulletin Biolog. 1, pp. 1-3.

Qu, H., Ma, R.X., Liu, D.H., Wang, P., Huang, L.D., Qiu, X.X., Zhou, Z.Q., 2014 Enantioselective toxicity and degradation of the chiral insecticide fipronil in Scenedesmus obliguus suspension system. Environ. Toxicol. Chem. 33 (11), 2516-2521. https://doi.org/10.1002/etc.2702.

Qu, H., Ma, R.X., Liu, D.H., Jing, X., Wang, F., Zhou, Z.Q., Wang, P., 2016. The toxicity, bioaccumulation, elimination, conversion of the enantiomers of fipronil in Anodonta woodiana. J. Hazard. Mater. 312, 169-174. https://doi.org/10.1016/j. jhazmat.2016.03.063.

Ramesh, A., Balasubramanian, M., 1999. Kinetics and hydrolysis of fenamiphos, fipronil, and trifluralin in aqueous buffer solutions. J. Agric. Food Chem. 47 (8), 3367-3371. https://doi.org/10.1021/jf980885m. 
Relyea, R.A., 2006. The impact of insecticides and herbicides on the biodiversity and productivity of aquatic communities - response. Ecol. Appl. 16 (5 (Oct)), 2027-2034. https://doi.org/10.1890/1051-0761(206)016[2027:tioiah]2.0.co;2.

Relyea, R., Hoverman, J., 2006. Assessing the ecology in ecotoxicology: a review and synthesis in freshwater systems. Ecol. Lett. 9 (10 (Oct)), 1157-1171. https://doi.org/ 10.1111/j.1461-0248.2006.00966.x.

Roques, B.B., Lacroix, M.Z., Puel, S., Gayrard, V., Picard-Hagen, N., Jouanin, I., Perdu, E., Martin, P.G., Viguie, C., 2012. CYP450-dependent biotransformation of the insecticide fipronil into fipronil sulfone can mediate fipronil-induced thyroid disruption in rats. Toxicol. Sci. 127 (1), 29-41. https://doi.org/10.1093/toxsci/kfs094.

Ros, M., Goberna, M., Moreno, J.L., Hernandez, T., Garcia, C., Insam, H., Pascual, J.A., 2006. Molecular and physiological bacterial diversity of a semi-arid soil contaminated with different levels of formulated atrazine. Appl. Soil Ecol. 34 (2-3), 93-102. https://doi.org/10.1016/j.apsoil.2006.03.010.

Rouze, R., Mone, A., Delbac, F., Belzunces, L., Blot, N., 2019. The honeybee gut microbiota is altered after chronic exposure to different families of insecticides and infection by Nosema ceranae. Microbes Environ. 34 (3), 226-233. https://doi.org/10.1264/jsme2. ME18169.

Ruiu, L., 2015. Insect pathogenic bacteria in integrated pest management. Insects 6 (2), 352-367. https://doi.org/10.3390/insects6020352.

Sabater, C., Carrasco, J.M., 2001a. Effects of pyridaphenthion on growth of five freshwater species of phytoplankton. A laboratory study. Chemosphere 44 (8), 1775-1781. https://doi.org/10.1016/s0045-6535(00)00575-0.

Sabater, C., Carrasco, J.M., 2001b. Effects of the organophosphorus insecticide fenitrothion on growth in five freshwater species of phytoplankton. Environ. Toxicol. 16 (4), 314-320. https://doi.org/10.1002/tox.1038.

Sabater, S., Navarro, E., Guasch, H., 2002. Effects of copper on algal communities at different current velocities. J. Appl. Phycol. 14 (5), 391-398. https://doi.org/10.1023/a: 1022142227394.

Sabater, S., Guasch, H., Ricart, M., Romani, A., Vidal, G., Klunder, C., Schmitt-Jansen, M., 2007. Monitoring the effect of chemicals on biological communities. The biofilm as an interface. Anal. Bioanal. Chem. 387 (4), 1425-1434. https://doi.org/10.1007/ s00216-006-1051-8.

Sadaria, A.M., Sutton, R., Moran, K.D., Teerlink, J., Brown, J.V., Halden, R.U., 2017. Passage of fiproles and imidacloprid from urban pest control uses through wastewater treatment plants in northern California, USA. Environ. Toxicol. Chem. 36 (6), 1473-1482. https://doi.org/10.1002/etc.3673.

Sanchez-Bayo, F., Goulson, D., Pennacchio, F., Nazzi, F., Goka, K., Desneux, N., 2016. Are bee diseases linked to pesticides? - a brief review. Environ. Int. 89-90, 7-11. https://doi. org/10.1016/j.envint.2016.01.009.

Schagerl, M., Donabaum, K., 1998. Epilithic algal communities on natural and artificial substrata in the River Danube near Vienna (Austria). Arch. Hydrobiol. (2), 153-165.

Schlenk, D., Huggett, D.B., Allgood, J., Bennett, E., Rimoldi, J., Beeler, A.B., Block, D., Holder, A.W., Hovinga, R., Bedient, P., 2001. Toxicity of fipronil and its degradation products to Procambarus sp.: field and laboratory studies. Arch. Environ. Contam. Toxicol. 41 (3), 325-332.

Seguin, F., Druart, J.C., Le Cohu, R., 2001. Effects of atrazine and nicosulfuron on periphytic diatom communities in freshwater outdoor lentic mesocosms. Ann. Limnol. Int. J. Limnol. 37 (1), 3-8. https://doi.org/10.1051/limn/2001004.

Sena, D.W., Kulacki, K.J., Chaloner, D.T., Lamberti, G.A., 2010. The role of the cell wall in the toxicity of ionic liquids to the alga Chlamydomonas reinhardtii. Green Chem. 12 (6), 1066-1071. https://doi.org/10.1039/c000899k

da Silva, D.R.O., de Avila, L.A., Agostinetto, D., Bundt, A.D., Primel, E.G., Caldas, S.S., 2011. Pesticide occurrence in groundwater near irrigated rice fields. Quim Nova 34 (5), 748-752.

Srigiriraju, L., Semtner, P.J., Bloomquist, J.R., 2010. Influence of post-exposure temperature on the toxicity of insecticides to the tobacco-adapted form of the green peach aphid (Hemiptera: Aphididae). J. Entomol. Sci. 45 (2), 178-187. https://doi.org/10.18474/ 0749-8004-45.2.178.

Stark, J.D., Vargas, R.I., 2005. Toxicity and hazard assessment of fipronil to Daphnia pulex. Ecotoxicol. Environ. Saf. 62 (1), 11-16. https://doi.org/10.1016/j.ecoenv.2005.02.011.

Stratton, G.W., Corke, C.T., 1982. Toxicity of the insecticide permethrin and some degradation products towards algae and cyanobacteria. Environ. Pollut. Ser. A Ecol. Biol. 29 (1), 71-80. https://doi.org/10.1016/0143-1471(82)90055-1.
Supowit, S.D., Sadaria, A.M., Reyes, E.J., Halden, R.U., 2016. Mass balance of fipronil and total toxicity of fipronil-related compounds in process streams during conventional wastewater and wetland treatment. Environ. Sci. Technol. 50 (3), 1519-1526. https://doi.org/10.1021/acs.est.5b04516.

Szegedi, V., Bardos, G., Detari, L., Toth, A., Banczerowski-Pelyhe, I., Vilagi, I., 2005. Transient alterations in neuronal and behavioral activity following bensultap and fipronil treatment in rats. Toxicology 214 (1-2), 67-76. https://doi.org/ 10.1016/j.tox.2005.05.023.

Szivak, Ilona, Behra, Renata, Sigg, Laura, 2009. Metal-induced reactive oxygen species production in Chlamydomonas reinhardtii (Chlorophyceae). J. Phycol. 45 (2), 427-435. https://doi.org/10.1111/j.1529-8817.2009.00663.x.

Thoetkiattikul, H., et al., 2017. Culture-Independent Study of Bacterial Communities in Tropical River Sediment. Biosci. Biotechnol. Biochem. 81 (1), 200-209. https://doi. org/10.1080/09168451.2016.1234927 (Jan).

Toan, P.V., Sebesvari, Z., Blasing, M., Rosendahl, I., Renaud, F.G., 2013. Pesticide management and their residues in sediments and surface and drinking water in the Mekong Delta, Vietnam. Sci. Total Environ. 452, 28-39. https://doi.org/10.1016/j. scitotenv.2013.02.026.

Tousova, Z., Oswald, P., Slobodnik, J., Blaha, L., Muz, M., Hu, M., Brack, W., Krauss, M., Di Paolo, C., Tarcai, Z., Seiler, T.B., Hollert, H., Koprivica, S., Ahel, M., Schollee, J.E., Hollender, J., Suter, M.J.F., Hidasi, A.O., Schirmer, K., Sonavane, M., Ait-Aissa, S. Creusot, N., Brion, F., Froment, J., Almeida, A.C., Thomas, K., Tollefsen, K.E., Tufi, S., Ouyang, X.Y., Leonards, P., Lamoree, M., Torrens, V.O., Kolkman, A., Schriks, M. Spirhanzlova, P., Tindall, A., Schulze, T., 2017. European demonstration program on the effect-based and chemical identification and monitoring of organic pollutants in European surface waters. Sci. Total Environ. 601, 1849-1868. https://doi.org/ 10.1016/j.scitotenv.2017.06.032.

Uniyal, S., Paliwal, R., Sharma, R.K., Rai, J.P.N., 2016a. Degradation of fipronil by Stenotrophomonas acidaminiphila isolated from rhizospheric soil of Zea mays. 3 Biotech 6. https://doi.org/10.1007/s13205-015-0354-X.

Uniyal, S., Paliwal, R., Verma, M., Sharma, R.K., Rai, J.P.N., 2016b. Isolation and characterization of fipronil degrading Acinetobacter calcoaceticus and Acinetobacter oleivorans from rhizospheric zone of Zea mays. Bull. Environ. Contam. Toxicol. 96 (6), 833-838. https://doi.org/10.1007/s00128-016-1795-6.

USEPA, 2000. Risk based Concentration Table. United States Environmental Protection Agency, Philadelphia, PA; Washington DC.

Val, J., Muniz, S., Goma, J., Navarro, E., 2016. Influence of global change-related impacts on the mercury toxicity of freshwater algal communities. Sci. Total Environ. 540, 53-62. https://doi.org/10.1016/j.scitotenv.2015.05.042.

Vayias, B.J., Athanassiou, C.G., Buchelos, C.T., 2006. Evaluation of three diatomaceous earth and one natural pyrethrum formulations against pupae of Tribolium confusum DuVal (Coleoptera: Tenebrionidae) on wheat and flour. Crop Prot. 25 (8), 766-772. https:// doi.org/10.1016/j.cropro.2005.10.011.

Voigt, J., 1988. The lithium-chloride-soluble cell-wall layers of Chlamydomonasreinhardii contain several immunologically related glycoproteins. Planta 173 (3), 373-384. https://doi.org/10.1007/bf00401024.

Wang, W.H., Wang, H., Feng, Y.Z., Wang, L., Xiao, X.J., Xi, Y.G., Luo, X., Sun, R.B., Ye, X.F., Huang, Y., Zhang, Z.G., Cui, Z.L., 2016a. Consistent responses of the microbial community structure to organic farming along the middle and lower reaches of the Yangtze River. Sci. Rep. 6. https://doi.org/10.1038/srep35046.

Wang, X., Martinez, M.A., Wu, Q.H., Ares, I., Martinez-Larranaga, M.R., Anadon, A., Yuan, Z.H., 2016b. Fipronil insecticide toxicology: oxidative stress and metabolism. Crit. Rev. Toxicol. 46 (10), 876-899. https://doi.org/10.1080/10408444.2016.1223014.

Wu, J., Lu, J., Lu, H., Lin, Y.J., Wilson, P.C., 2015. Occurrence and ecological risks from fipronil in aquatic environments located within residential landscapes. Sci. Total Environ. 518, 139-147. https://doi.org/10.1016/j.scitotenv.2014.12.103.

Xia, N., et al., 2013. Bacterial Diversity and Community Structure in the Sediment of the Middle and Lower Reaches of the Yellow River, the Largest Turbid River in the World. Aquat. Microb. Ecol. 71 (1). https://doi.org/10.3354/ame01664 43-U168.

Zhang, W.J., She, D.Q., Shi, J., Fan, S.S., Zhou, L., Hu, Y.T., Yuan, L., 2017. The effect of different medium on enantioselectivity in degradation of bifenthrin. J. Nanosci. Nanotechnol. 17 (4), 2637-2644. https://doi.org/10.1166/jnn.2017.12700. 